\title{
Stratigraphy of the Arisaig Group
}

THOMAS E. IANE and LYNDON R. JENSEN

Department of Geology, Dalhousie University, Halifax, Nova Scotia

\section{Introduction}

The Arisaig Group is a continuous sedimentary succession ranging in age from earliest silurian to early Devonian (Fig. 1). The succession is exposed on the coast to the west of Cape George, Nova Scotia. The Group is composed primarily of alternating strata $(1$ to $120 \mathrm{~cm}$ thick) of siltstone and mudstone with subsidiary very finegrained sandstone and shelly limestone (coquinite). These strata have been openly folded and offset by vertical faults during Devonian and Carboniferous times. The rocks are highly fossiliferous. Studies of bivalves by Bambach (1969), brachiopods by Harper (1973) and Watkins and Boucot (1975), and graptolites by Berry and Boucot (1970) suggest that the faunal communities developed mainly in shallow-marine (depth of water less than $6 \mathrm{~m}$ ) to brackish-vater environments.

Stops 12,13 and 14 of the Eastern Section SEPM Field Trip (Harris, this volume) are at coastal exposures of the Beechill Cove, Ross Brook (upper member and upper middle member), Moydart, and Stonehouse Formations of the Arisaig Group (Fig. 2). The sedimentary characteristics of these rocks are discussed in this paper and illustrated in the photographs that appear as Figures 5 to 36 and 38 to 46 inclusive.

The Arisaig strata disconformably overlie Upper Ordovician, mainly volcanic rocks (andesites and rhyolites) of the Bear Brook Volcanic Group. The presence of ignimbrites and lateritic paleosoil horizons in the upper portion of the Bear Erook Volcanic Group indicates subaerial conditions. The Bear Brook volcanics unconformably overlie deformed and intruded volcanic and sedimentary strata of the Browns Mountain Group (Eocambrian? Crdovician?).

During deposition of the Arisaig Group, a rich benthonic fauna thrived on a generally muddy sea-bottom. Skeletal debris, fine-grained sandstone and siltstone occur both as discontinuous lenses and laterally continuous beds that record short-term episodes of relatively high-energy sedimentation. These strata typically have sharply defined and commonly erosional bases and sharply defined to gradational tops. Parallel-lamination and cross-lamination are common internal structures. Coquinas generally occur as isolated lenses in scour-depressions.

The mudstone beds tend to be structureless, aue in part to extensive bioturbation. Fossils preserved in their life positions suggest that the mudstones generally were deposited slowly. Conversely, fossils in the coarser-grained beds generally occur as transported thanatocoenoses, suggesting relatively rapid deposition. These sedimentary and faunal characteristics, with minor variations, are representative of the Arisaig strata. The depositional history of the Arisaig
Group is summarized in Figures 3 and 4.

Paleocurrent data indicate that the currents were mainly from the northeast, although in the Upper Stonehouse Formation the dispersal trend is from the southeast. The paleogeography is poorly known because of the limited area of outcrop and because the inland exposures tend to be poor. Additional paleocurrent data are needed in order to delineate the complex littoral current directions and to determine their relation to the paleocoastIine.

Beechhill Cove Formation (Stop 12)

The Beechilil Cove Formation consists of massively bedded and poorly sorted siltstone with interbeds of sandstone and silty mudstone. This unit overlies an eroded volcanic terrain of subaerial lava flows, ignimbrites and laterites (the Bears Brook Volcanic Group), and conformably but abruptly underlies black shale of the lower Ross Brook Formation. These strata were deposited during a major transgression, which possibly was related to the climatic and glacio-eustatic sea-level changes that affected much of the world in wate ordovician and Early silurian times.

The base of the formation is exposed at two outcrops in the vicinity of Stop 12 (Harris, this volume). At the first outcrop, near Arisaig Pier, an oligomictic conglomerate caps the eroded volcanics of the Bears Brook Volcanic Group (Fig. 5). The clasts are almost exclusively of rhyolite and ignimbrite. The conglomerate is variable in thickness and pinches out along strike. It possibly was deposited in terrestrial stream channels. The contact with the overlying marine sediments is transitional.

Ft the second locality, $3 / 4 \mathrm{~km}$ to the east, mudstone with thin sandstone lenses directly overlies ignimbrites (Fig. 6) and passes upwards into mudstone with relatively thick-bedded, lenticular sandstone (Fig. 7). The sandstones fill scours 30 to $300 \mathrm{~cm}$ across and up to $25 \mathrm{~cm}$ deep (Fig. 8). The basal portion of such scour-and-fill structures commonly are filled with coquinas of disarticulated, unfragmented brachiopods. Internally, the coquina lenses tend to be ungraded and to have low-angle cross-lamination.

The succeeding strata include thick beds of massive siltstone, which possibly were deposited rapidly from currents that carried large volumes of silt in suspension. Conversely, the massive character of the beds may be due to extensive bioturbation that homogenized the sediment and obliterated most of the original sedimentary structures. Intercalated mudstones increase in abundance toward the top of the formation, and at the top, laminated siltstone alternates with greenish-grey silty mudstone in approximately equal proportions. 


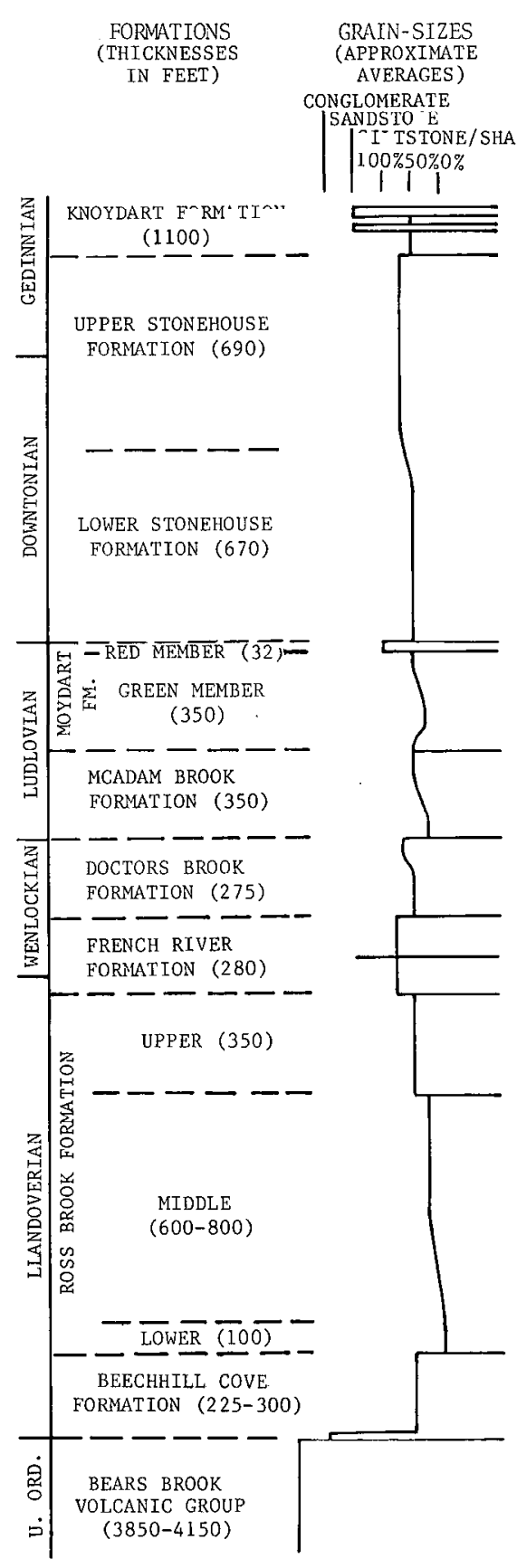 (FROM FAUNA AND
SEDIMENT TYPE)

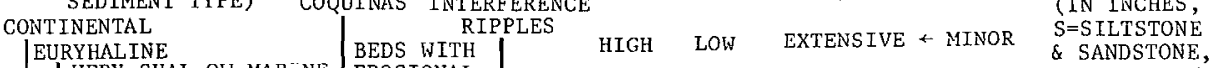 M=MUDSTONE) THALLOW MARINE

\section{REDBEDS}
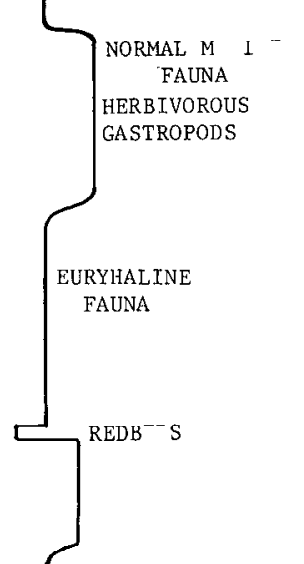

EURYHALTNE

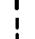

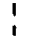

EURYHALINE FAUNA
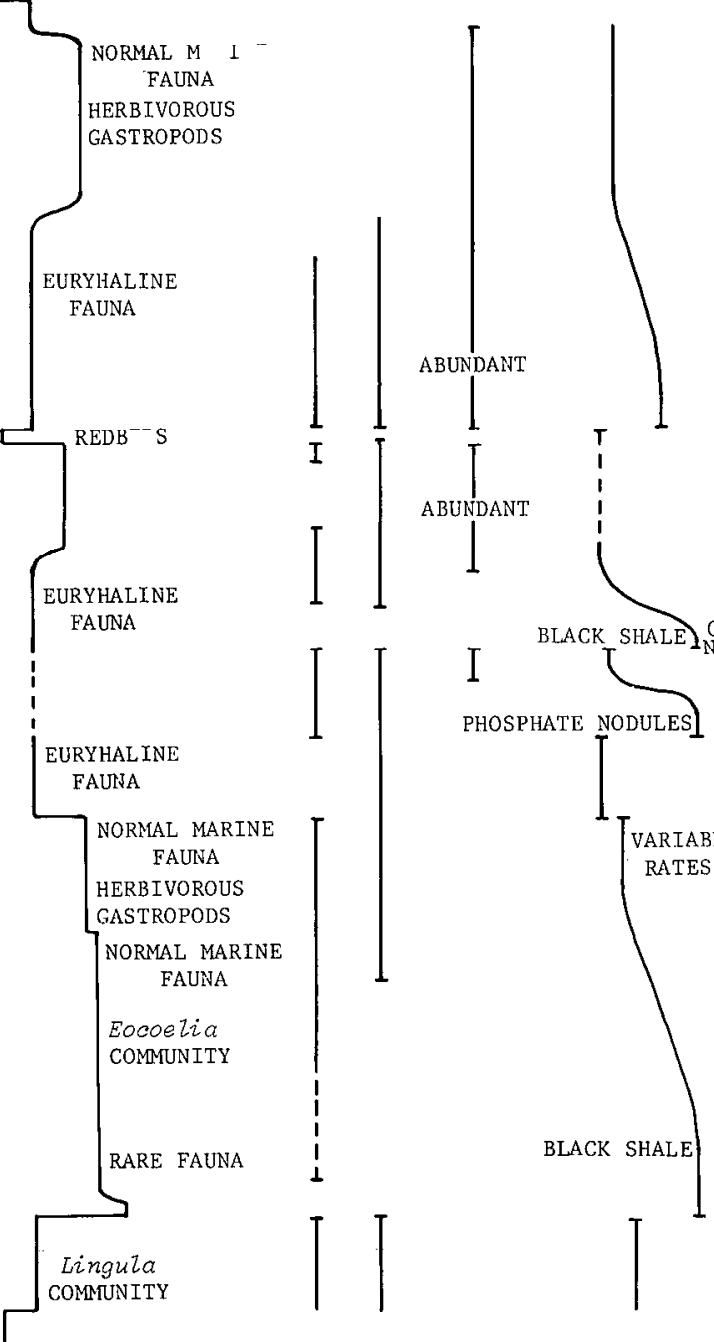

MUDSTONES IOTURBATED

S $1-12$

I BLACK SHAL CALC.

PHOSPHATE NODULES

\section{BTOTURBATED}

VERTICAL BURROWS S,M I-12

, M $1-12$

$\mathrm{S} 2-224$
$\mathrm{M} 2-18$
$\mathrm{~S}=18$

S $\mathrm{S}-1 \frac{1}{2}-36$

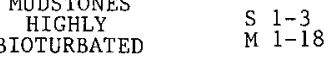

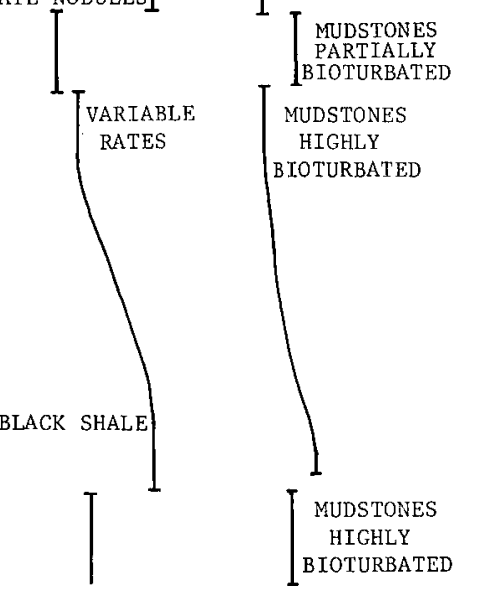

S
$M$
$M$
$1-7$

$\operatorname{Sic}_{\mathrm{M}} \mathrm{1}^{1-2}$

S $\frac{1}{4}-2$

SILTSTONE

S, M $\frac{1}{2}-18$

Fig. I Stratigraphy of the Arisaig Group, Arisaig, Nova Scotia. 
GEOLOGIC MAP OF THE ARISAIG AREA

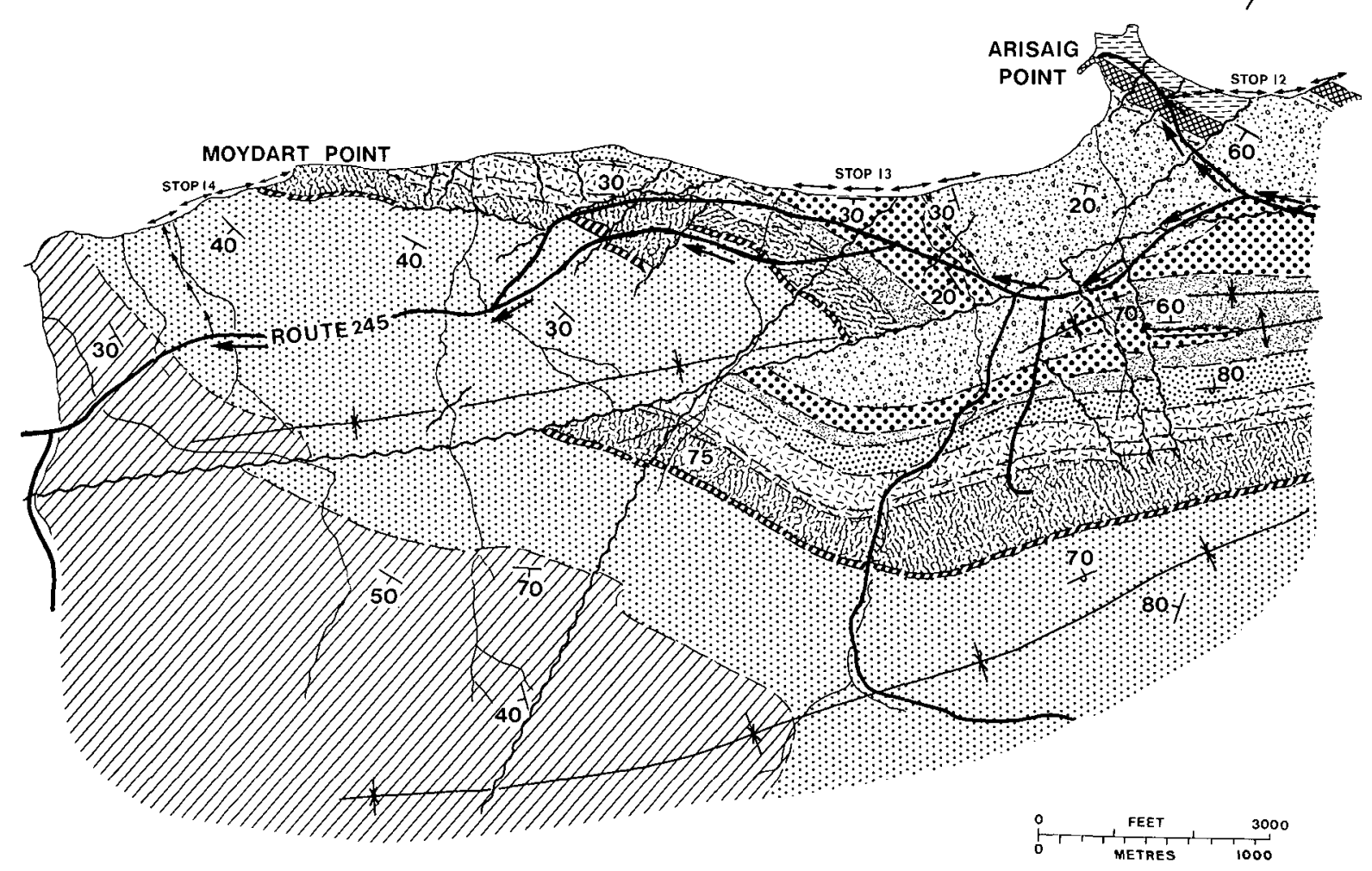

1 DIIA KNOYDART FORMATION

ARISAIG GROUP

STONEHOUSE FORMATION

MOYDART FORMATION

VIIIIII UPP $\triangle R$ MEMB_R

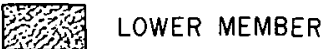

SCAD BDAM BROOK FORMATION

DO DOCTOR'S BROOK FORMATION

FRENCH RIVER FORMATION

ROSS BROOK FORMATION

UPPER MEMBER

MIODLE MEMBER

LOWER MEMBER

beachHill cove formation

P

BEAR'S BROOK GROUP

FIG. 2 


\begin{tabular}{|c|c|c|c|c|c|c|}
\hline \multirow{2}{*}{ 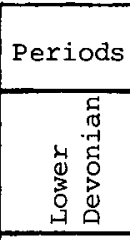 } & STAGES & \multicolumn{3}{|c|}{ ROCK UNITS } & LITHOLOGY & $\begin{array}{l}\text { GENERALIZED } \\
\text { DEPOSITIONAL } \\
\text { ENVIRONMENT } \\
\end{array}$ \\
\hline & \multicolumn{2}{|l|}{ Gedinnian } & \multicolumn{2}{|l|}{$\begin{array}{l}\text { Znoydart } \\
\text { Formation }\end{array}$} & $\begin{array}{l}\text { red and green mudstone cyclically } \\
\text { interbedded with red sandstone and } \\
\text { some conglomerate }\end{array}$ & $\begin{array}{l}\text { delta flood-plain and } \\
\text { fluviatile }\end{array}$ \\
\hline \multirow{10}{*}{ 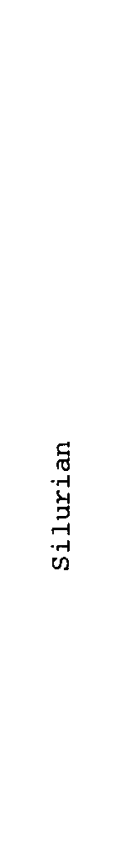 } & Downtonian & & \multicolumn{2}{|c|}{$\begin{array}{l}\text { Stonehouse } \\
\text { Formation }\end{array}$} & $\begin{array}{l}\text { interbedded siltstone, sandstone, } \\
\text { mudstone and minor shale and } \\
\text { limestone }\end{array}$ & $\begin{array}{l}\text { shallow marine (with possible } \\
\text { fluctuations of water depth } \\
\text { within the formation) }\end{array}$ \\
\hline & \multirow{3}{*}{ Ludlovian } & \multirow{5}{*}{ 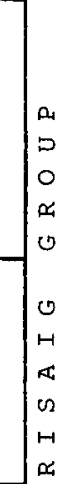 } & \multirow{2}{*}{$\begin{array}{l}\text { Moydart } \\
\text { Formation }\end{array}$} & $\begin{array}{l}\text { Red } \\
\text { Member }\end{array}$ & red marl and nodular limestone & terrestrial (flood-plain?) \\
\hline & & & & $\begin{array}{l}\text { Green } \\
\text { Member }\end{array}$ & $\begin{array}{l}\text { siltstone, mudstone and minor } \\
\text { limestone }\end{array}$ & shallow normal marine \\
\hline & & & \multicolumn{2}{|c|}{$\begin{array}{l}\text { McAdam Brook } \\
\text { Formation }\end{array}$} & $\begin{array}{l}\text { predominantly shale and mudstone } \\
\text { with minor siltstone and limestone }\end{array}$ & \multirow{3}{*}{$\begin{array}{l}\text { euryhaline environment } \\
\text { of deposition (fairly } \\
\text { shallow?) }\end{array}$} \\
\hline & \multirow{2}{*}{ Wenlockian } & & \multicolumn{2}{|c|}{$\begin{array}{l}\text { Doctor's Brook } \\
\text { Formation }\end{array}$} & $\begin{array}{l}\text { predominantly mudstone with some } \\
\text { shale and limestone }\end{array}$ & \\
\hline & & & \multicolumn{2}{|c|}{$\begin{array}{l}\text { French River } \\
\text { Formation }\end{array}$} & $\begin{array}{l}\text { mainly siltstone with shale also } \\
\text { containing some oolitic iron-rich } \\
\text { sediments }\end{array}$ & \\
\hline & \multirow{4}{*}{ Llandoverian } & \multirow{4}{*}{ 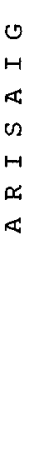 } & \multicolumn{2}{|c|}{ Upper Ross Brook Fm. } & $\begin{array}{l}\text { Interbedded siltstone, mudstone } \\
\text { and minor limestone }\end{array}$ & \multirow{3}{*}{$\begin{array}{l}\text { normal marine getting } \\
\text { progressively shallower } \\
\text { near top }\end{array}$} \\
\hline & & & \multicolumn{2}{|c|}{ Middle Ross Brook Fm. } & Interbedded mudstone and siltstone & \\
\hline & & & \multicolumn{2}{|c|}{ Lower Ross Brook Fm. } & Dark shales with minor siltstone & \\
\hline & & & \multicolumn{2}{|c|}{ Beechhill Cove Fm. } & $\begin{array}{l}\text { mainly siltstone with minor sand- } \\
\text { stone, mudstone and conglomerate }\end{array}$ & nearshore shallow marine \\
\hline
\end{tabular}

Fig. 3 Rock types and depositional environments of the Arisaig Group. 


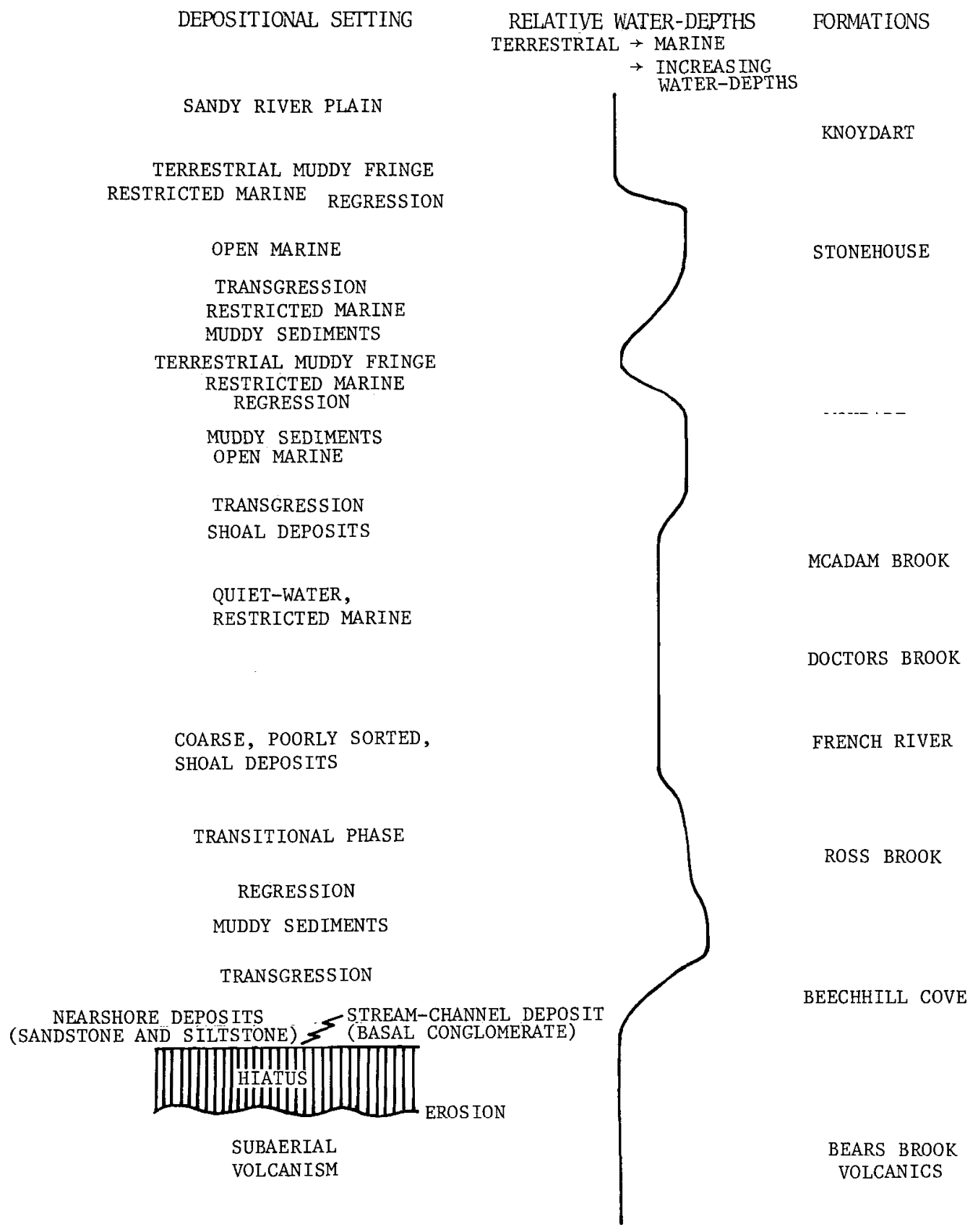

Fig. 4 Depositional environments of the Arisaig Group. 


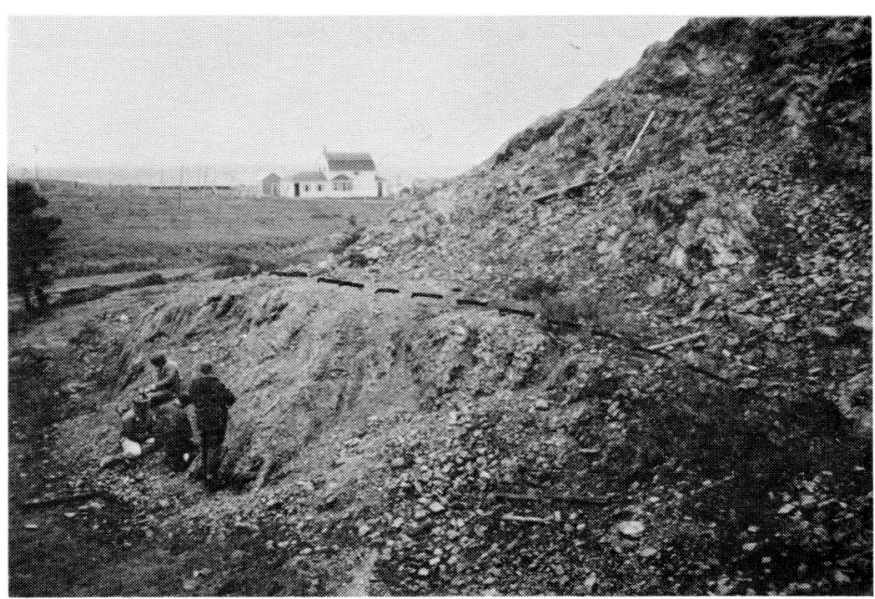

Fig. 5 Conglomerate of the Beechhill Cove Formation (below the dashed line) uncorformably overlying volcanic rocks of the Bear Brook Volcanic Group, near Arisaig pier (Stop 12).

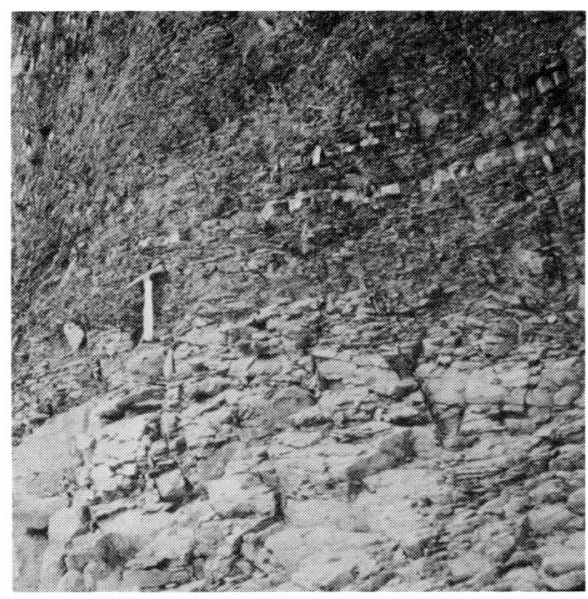

Fig. 6 Fine-grained basal beds of the Beechhill Cove Formation overlying ignimbrite of the Bear Brook Volcanic Group (northeast of Arisaig pier). Butt of hammer indicates the contact.

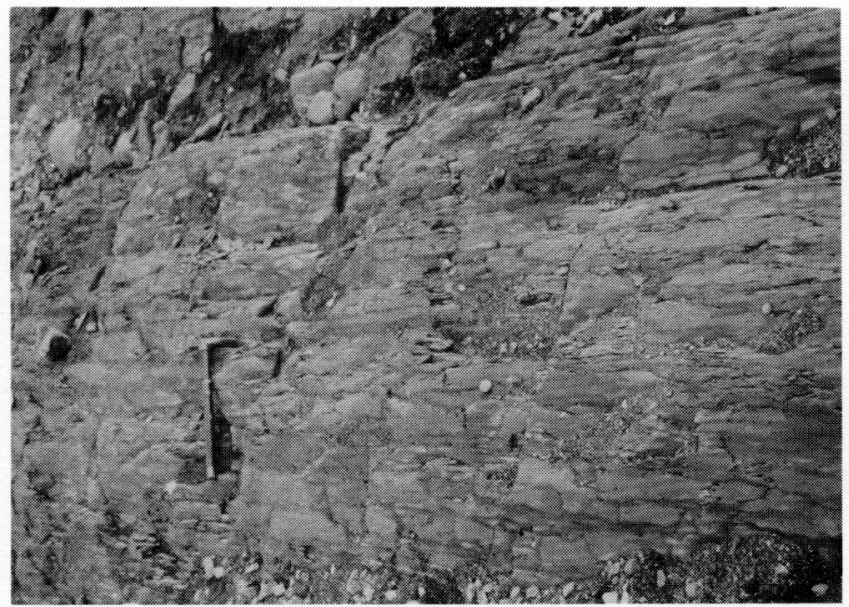

Fig. 7 Massive siltstone, lower part of Beechhill Cove Formation (Stop 12).

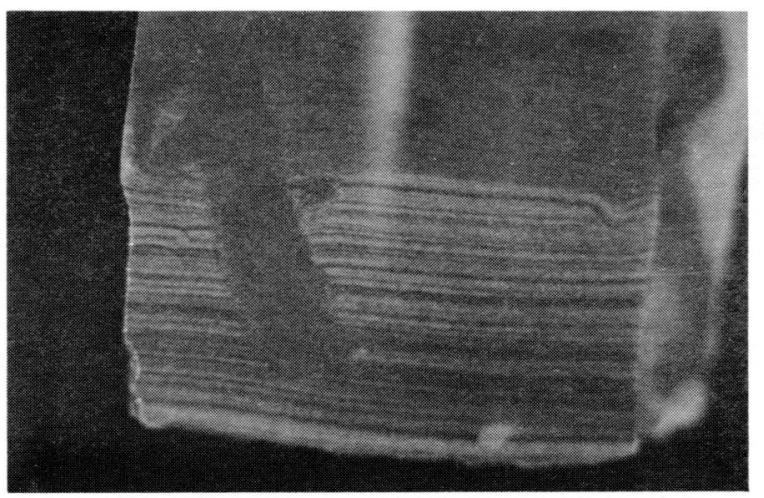

Fig. 9 Parallel laminae in siltstone, interrupted by sub. vertical burrows, middle member, Ross Brook Formation (Stop 13).

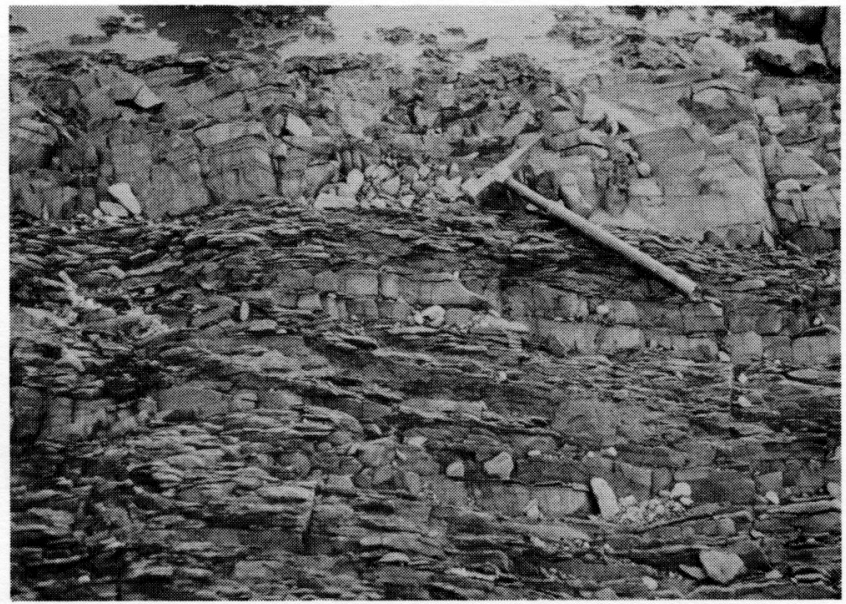

Fig. 8 Lenticular siltstone and sandstone intercalated with mudstone in the basal part of the Beechhill Cove Formation $\left(S_{\text {ton }}, 12\right)$.

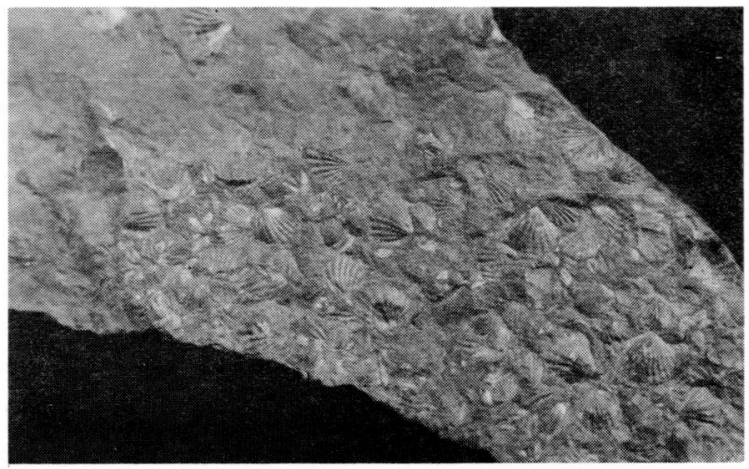

Fig. 10 Eocoelia cluster, middle member, Ross Brook Formaion (Stop 13). 
The fauna of this formation is dominated by linguloid brachiopods. These Lower Silurian fossils are primary members of brackish or very shallow marine water (Ziegler, 1965). Rugosan corals have been found as well. Their ecology is little known, except that these primitive Silurian species appear to have inhabited clear, shallow water in other areas.

\section{Ross Brook Formation (Stop 13)}

The Ross Brook Formation (280 m thick), is a coarsening-upward succession of dark shales and thin siltstones that contain a marine fauna. The formation is divided into three members on the basis of lithologic distinctions. The lower member is $25 \mathrm{~m}$ thick and consists of fissile, micro-laminated black shale with graptolites and rare brachiopods. The middle member is a $180-\mathrm{m}$ thick transition zone between the lower and upper members. The upper $90 \mathrm{~m}$ of the middle member consists of greenish grey mudstones with thin intercalations ( 0.5 to $1 \mathrm{~cm}$ thick) of siltstone (siltstone/mudstone ratio approximately $1 / 10$, Fig. 12). The mudstones commonly have a massive appearance and contain many burrowing structures. These rocks contain a varied fauna, the most diagnostic of which is the brachiopod Eocoelia (Fig. 10). This fauna has been designated as distinctly Early Silurian and shallow-marine (Ziegler, 1965).

The siltstones of the upper member of the Ross Brook Formation occur both as relatively thin beds that are laterally continuous in outcrop and as thicker beds that commonly are lenticular and have uneven lower and upper surfaces. Many of the thicker beds occur sandwiched between layers of thinly interbedded shale and siltstone (Figs. 14 and 21). Bottom-surface irregularities characterize many of the siltstone beds and may have resulted partly from erosion by relatively high-energy (storm-generated?) currents.

Some of the siltstone beds occur in groups that form thickening-upward sequences (Figs. 14 and 17). Such rhythms possibly indicate seasonal cycles of sedimentation. It is possible that the thicker siltstone beds were deposited from currents generated by seasonal storms. Groups of beds in which mudstone predominates may denote seasons during which storms tended to be infrequent, or during which the discharge of mud from riverestuaries along the coast was relatively high.

The siltstone beds have many of the characteristics of the storm-related strata described by Lane (Recent Shoreline to Shelf Sedimentary Facies ...., this volume). The lower contacts of the siltstone beds generally are sharp and the under-surfaces either are flat and structureless or are irregular due to the presence of loaded scour-depressions (Figs. 23 and 26). The beds tend to be laminated, with the laminae commonly less than $1 \mathrm{~mm}$ thick. Some of the beds lack internal structures, except for parallel-lamination near the tops of the beds where the mica content tends to be high. Beds with gently inclined crosslamination (possible megaripples) are present here and there in the upper member (Figs. 22 and 24).
The megaripples(?) presumably developed on the seafloor during storms. Composite beds, composed of alternating layers and lenses of parallel-laminated, finely cross-laminated and structureless siltstone, are common (Figs. 16 and 18). Many of the beds have sharp upper contacts, but thin gradational zones at the tops of the beds are common as well. The grading is most pronounced in siltstone beds that are mud-rich. Ripple marks and ripple cross-lamination occur at or near the tops of many of these beds and may reflect the waning of storm-generated currents.

These strata contain numerous fossils, which tend to be concentrated at the interfaces of mudstone and siltstone beds. In situ biocoenoses are found at the upper surface of mudstone beds, whereas transported thanatocoenoses occur as coquinites at the bases of a number of beds. These coquinites consist primarily of carbonate debris (mainly shell fragments) and calcite cement, and typically occur as lenses in scour-depressions (Fig. 22).

The mudstones tend to be highly bioturbated and, as a consequence, internal structures are poorly preserved. Vertical burrows are abundant. Suspension -feeding bivalves commonly are preserved in their Iife positions. The presence of these organisms suggests that relatively clear-water conditions prevailed for much of the time. However, the siltstone beds probably were deposited during relatively short-lived episodes of turbulence and high-sediment influx, during which local populations of the bottomdwelling organisms may have largely perished.

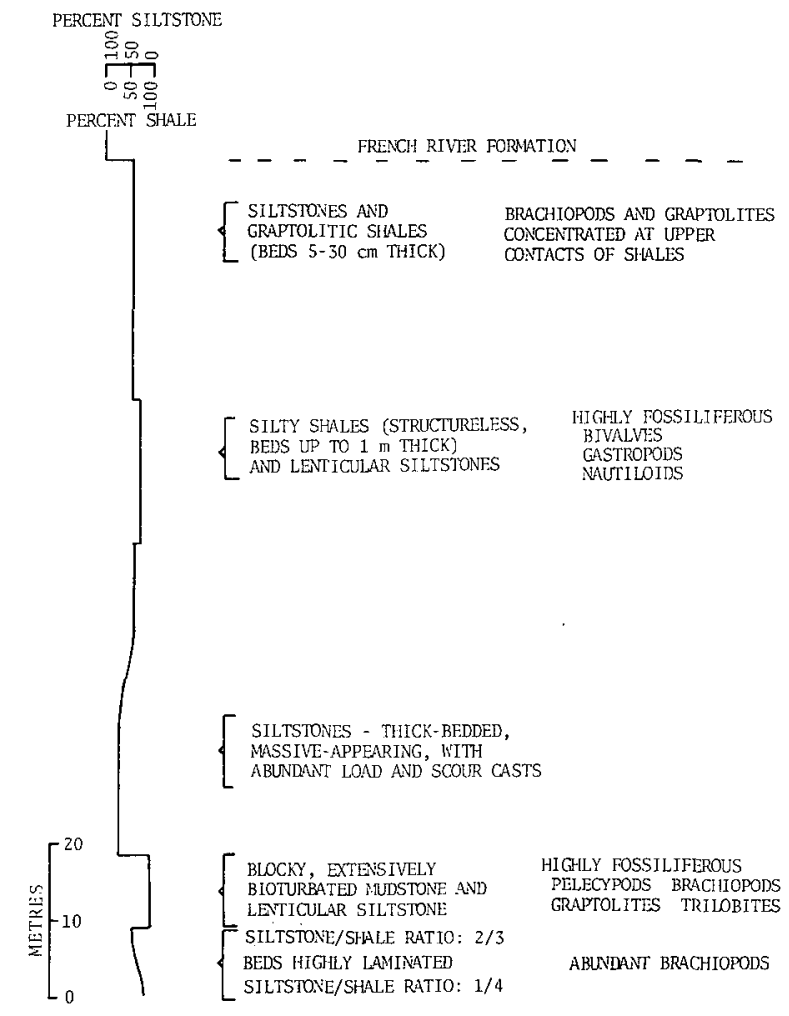

Fig. 11 Lithology and fauna of the upper member of the Ross Brook Formation (after Bambach, 1969). 


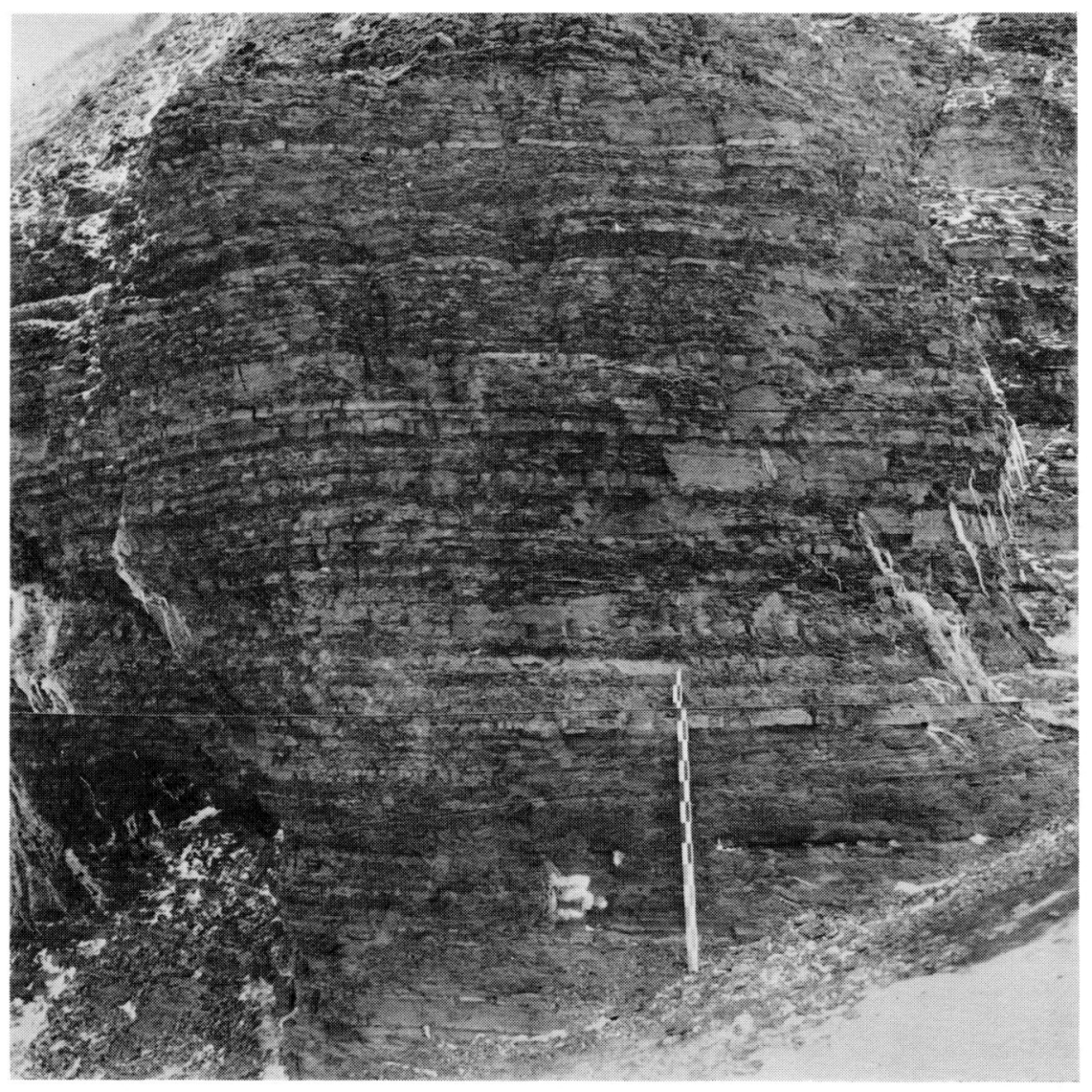

Fig. 12 Interbedded siltstone and mudstone, middle member of the Ross Brook Formation (Stop 13). Note upward increase in number and thickness of siltstone beds. Each division of $1.5 \mathrm{~m}$ meosuring stick is $10 \mathrm{~cm}$ long.

Fig. 13 Interbedded siltstone and mudstone, upper member, Ross Brook Formation (Stop 13). Note fairly abrupt thinning of siltstone beds and their sharp, erosional bases. Eoch division of meosuring stick is $10 \mathrm{~cm}$ long.

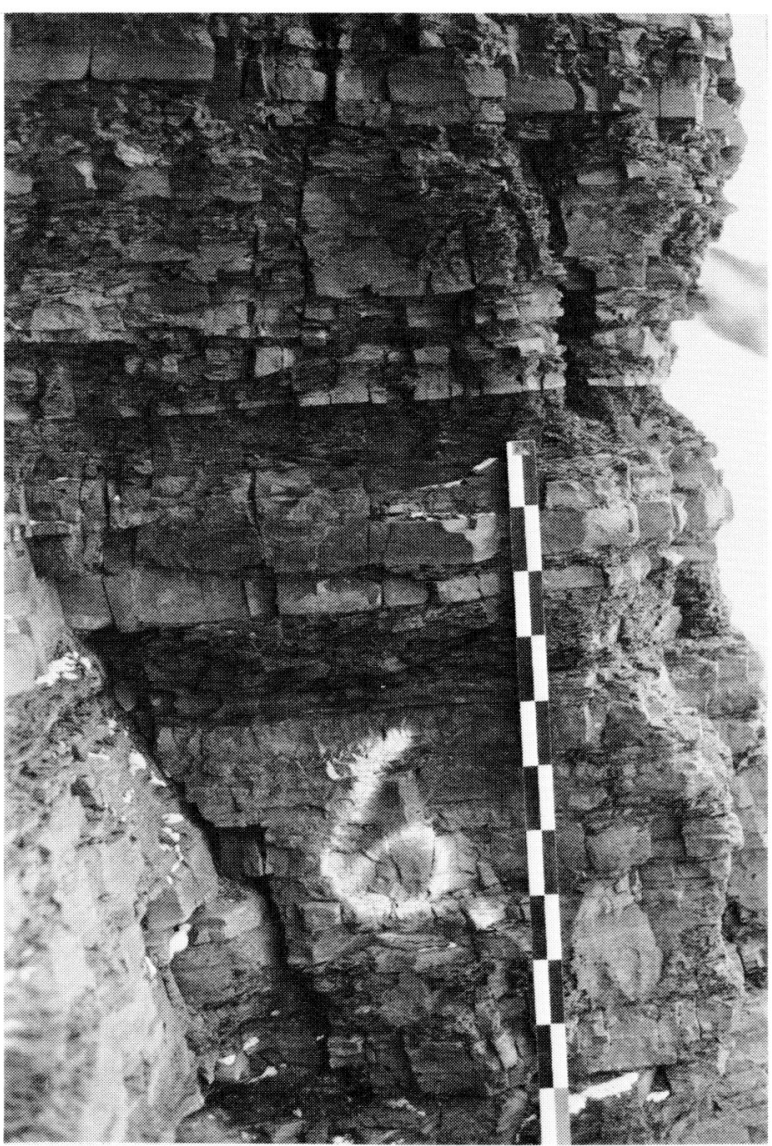




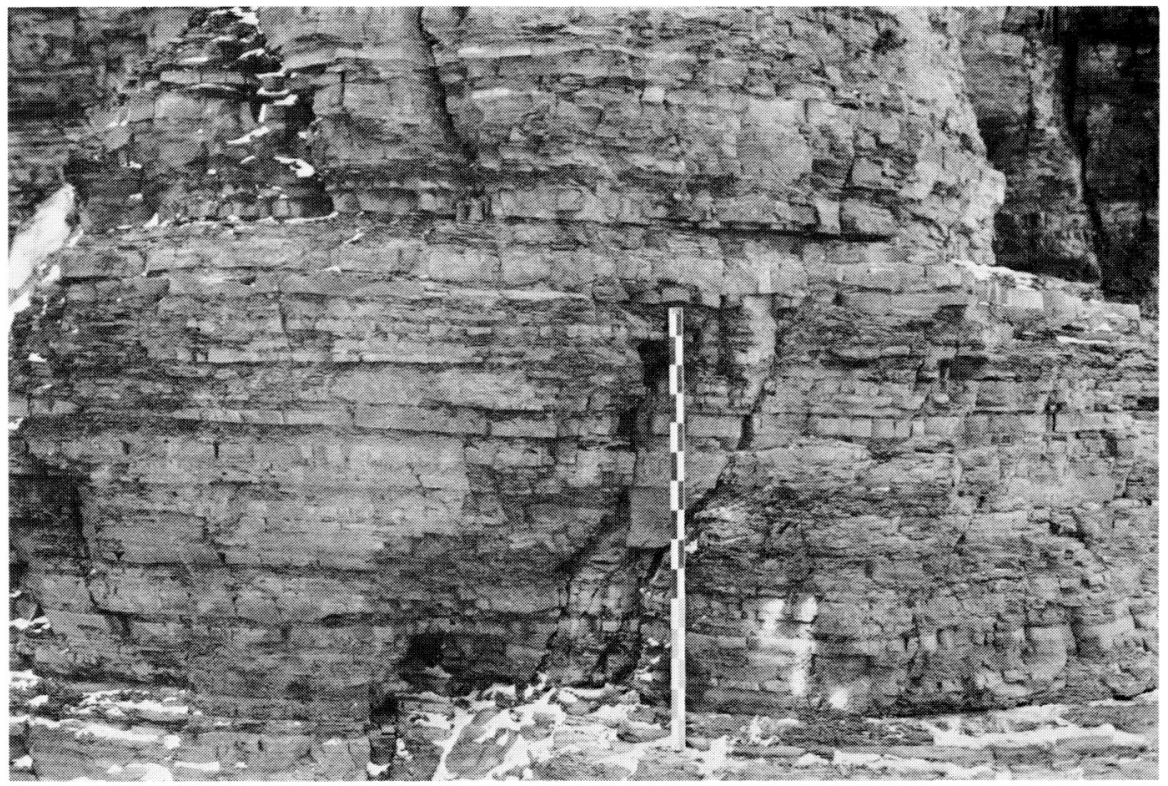

Fig. 14 Interbedded siltstone and mudstone near base of the upper member, Ross Brook Formation, (Stop 13). Each division of measuring stick is $10 \mathrm{~cm}$ long.

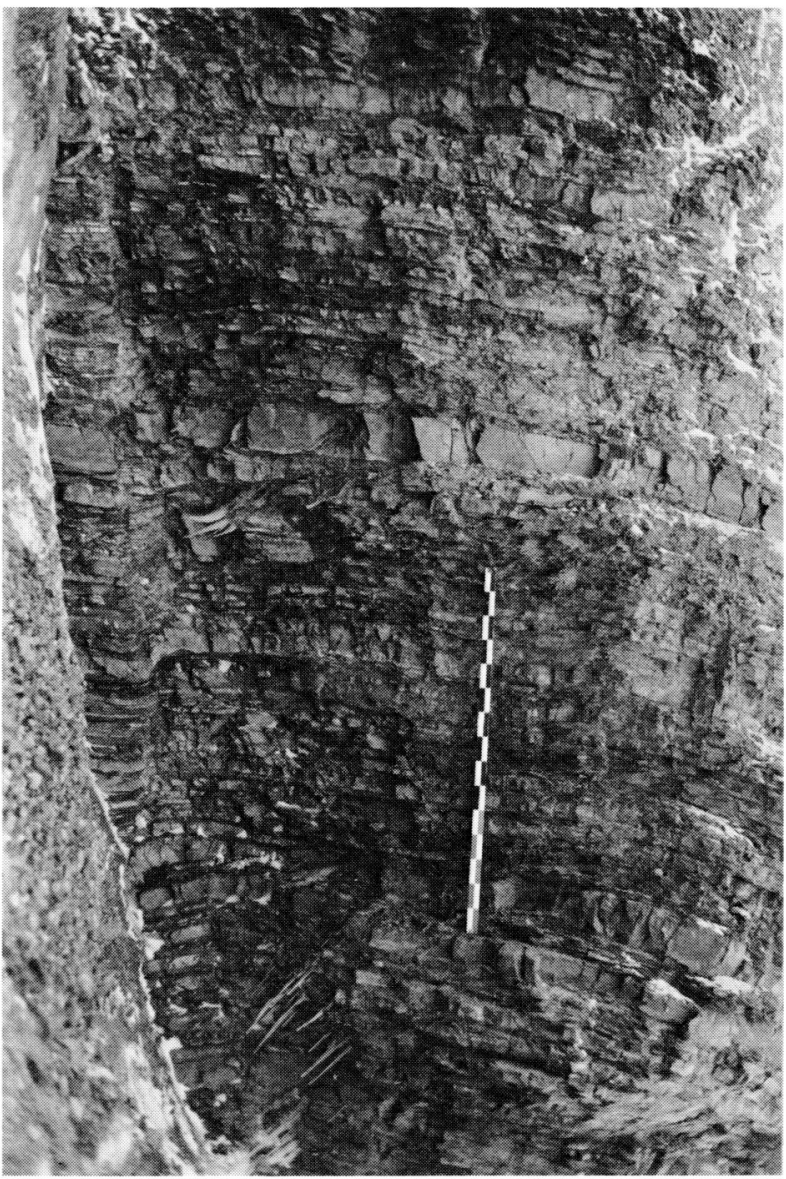

Fig. 15 Interbedded siltstone and mudstone, upper member, Ross Brook Formation (Stop 13). Note large number and relatively great thick. nesses of the siltstone beds. Divisions on measuring stick are each $10 \mathrm{~cm}$ long. Photo is rotated so that steeply dipping beds appear nearly horizontal. 


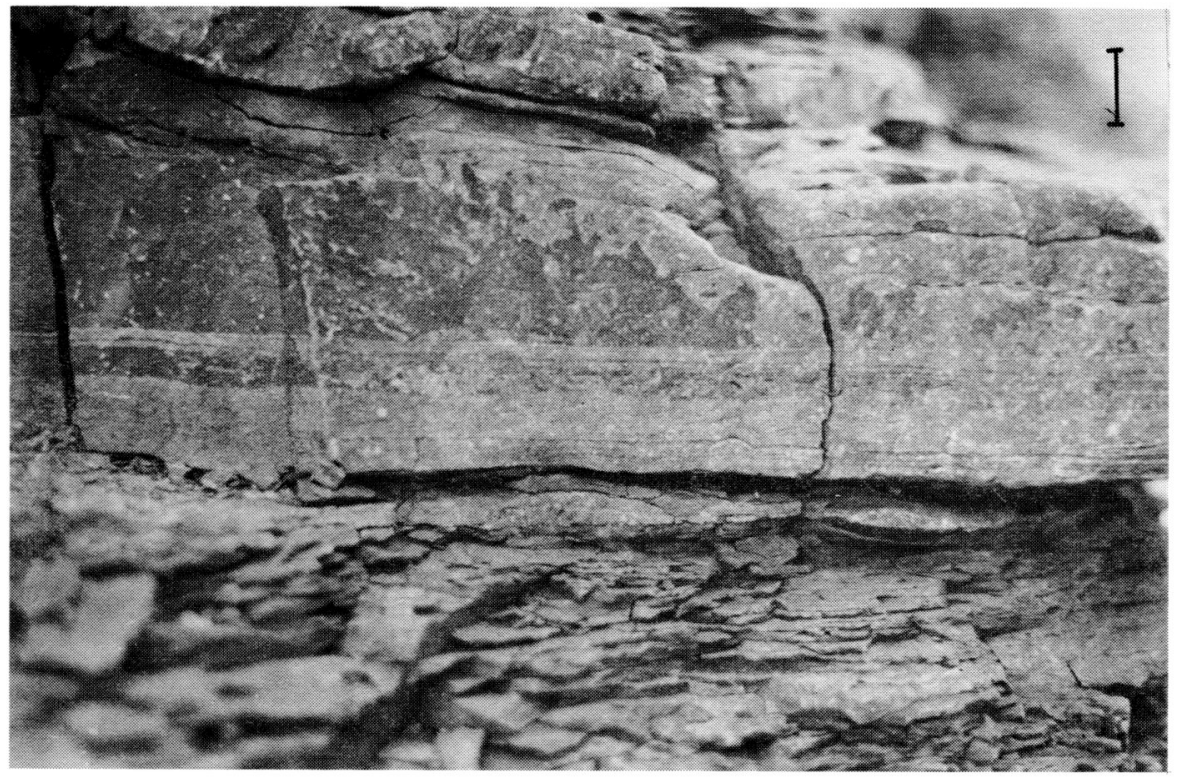

Fig. 16 Intercalated siltstone and mudstone, upper member, Ross Brook Formation (Stop 13). The relatively resistant layer in the middle part of picture cono sists of parallel and cross-laminated muddy siltstone. The siltstone grades into mudstone. Bar at upper right reo presents approximately $2 \mathrm{~cm}$.

Fig. 17 Interbedded mudstone and siltstone, upper member, Ross Brook Formation, showing thickening upward sequences (a characteristic of this part of the section) (Stop 13). Each division of measuring stick is $10 \mathrm{~cm}$ long.
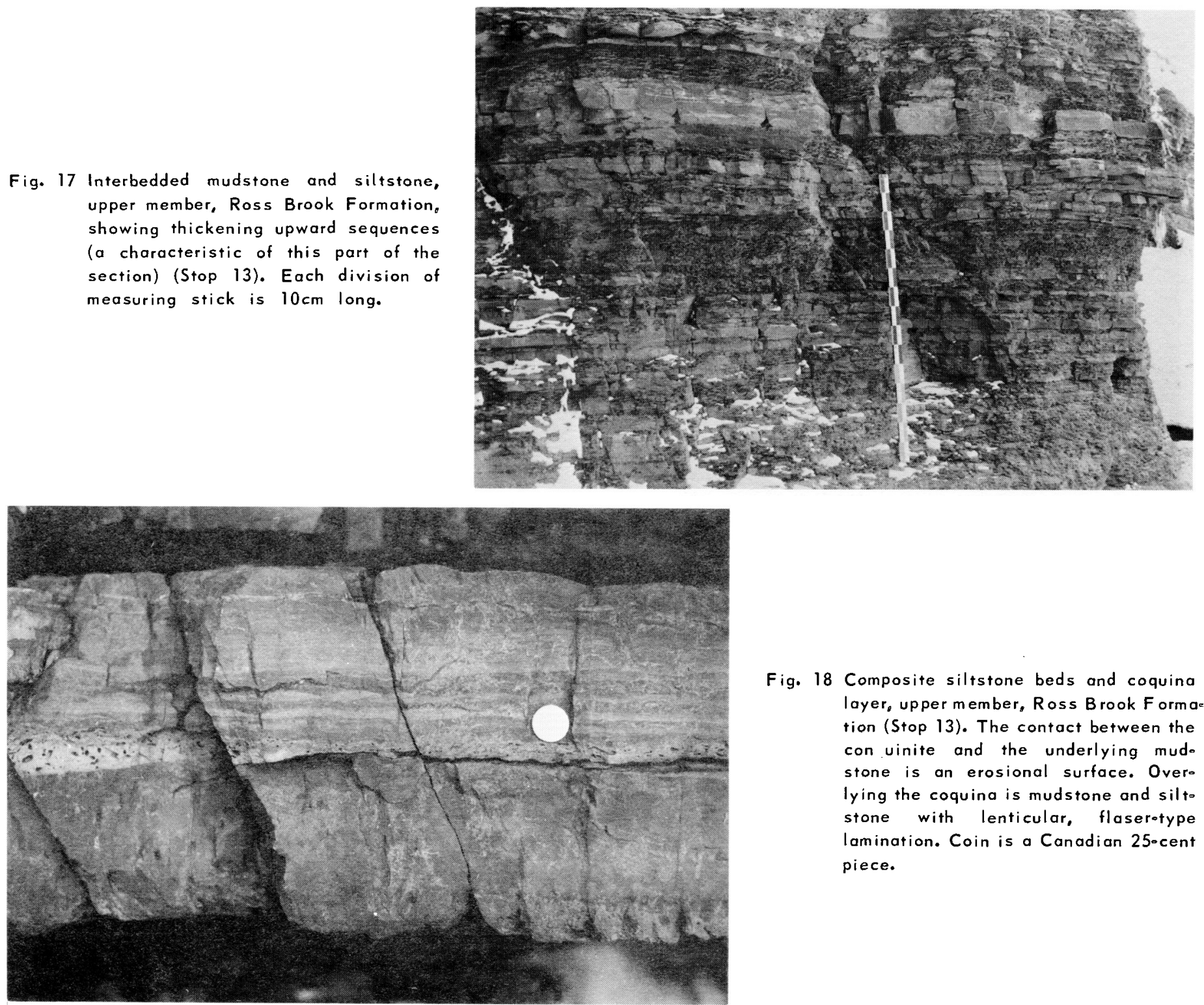

Fig. 18 Composite siltstone beds and coquina layer, upper member, Ross Brook F orma. tion (Stop 13). The contact between the con uinite and the underlying mudo stone is an erosional surface. Overo lying the coquina is mudstone and silto stone with lenticular, flaserotype lamination. Coin is a Canadian 25-cent piece. 
Fig. 19 Interbedded siltstone and mudstone, upper member, Ross Brook Formation (Stop 13). Note lenticular nature of the silistone beds. Each division of mea suring stick is $10 \mathrm{~cm}$ long.
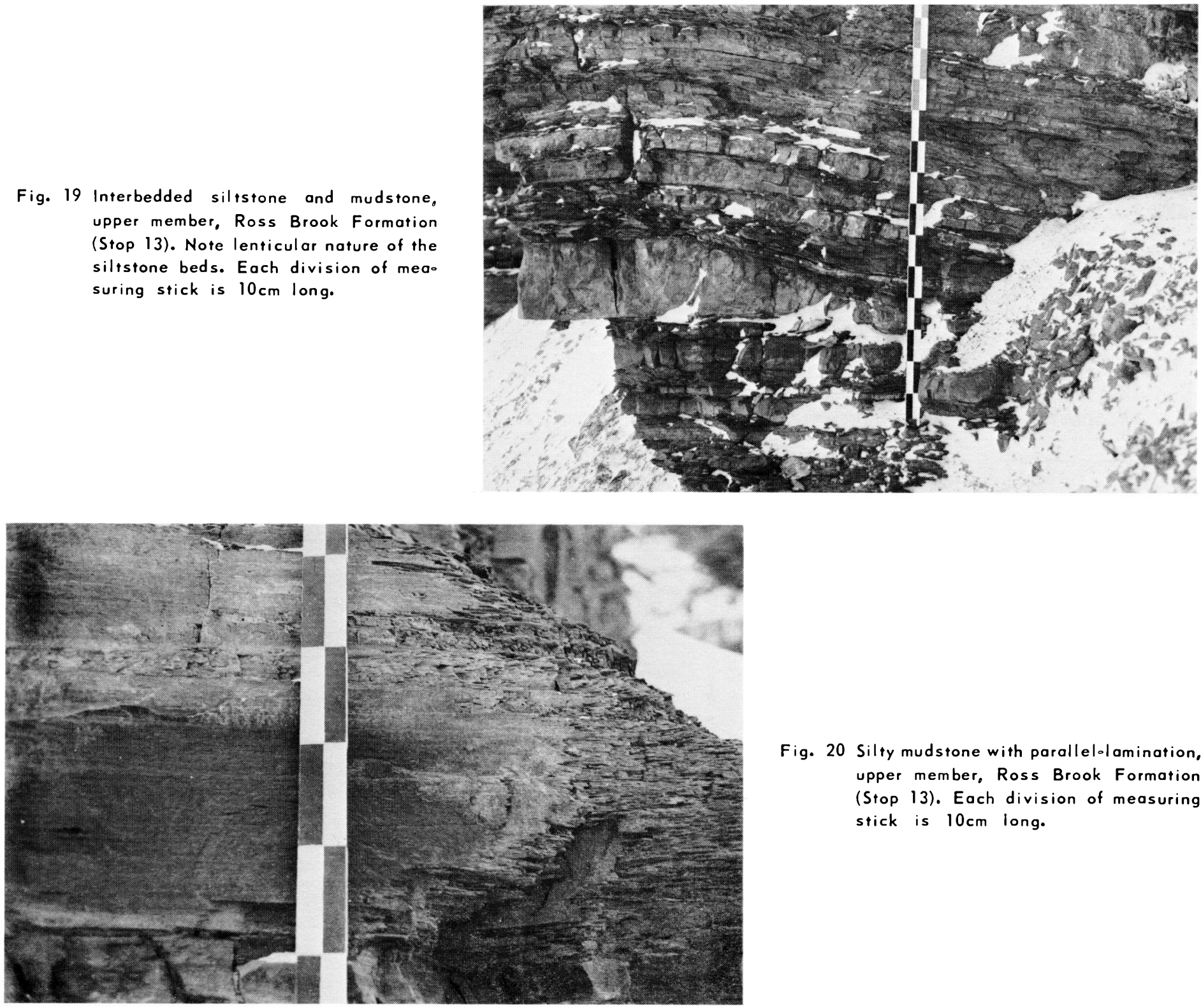

Fig. 20 Silty mudstone with parallelolamination, upper member, Ross Brook Formation (Stop 13). Each division of measuring stick is $10 \mathrm{~cm}$ long.

Fig. 21 Relatively thick beds of siltstone and thin intercalations of mudstone, upper member, Ross Brook Formation (Stop 13). Each division of measuring stick is $10 \mathrm{~cm}$ long.

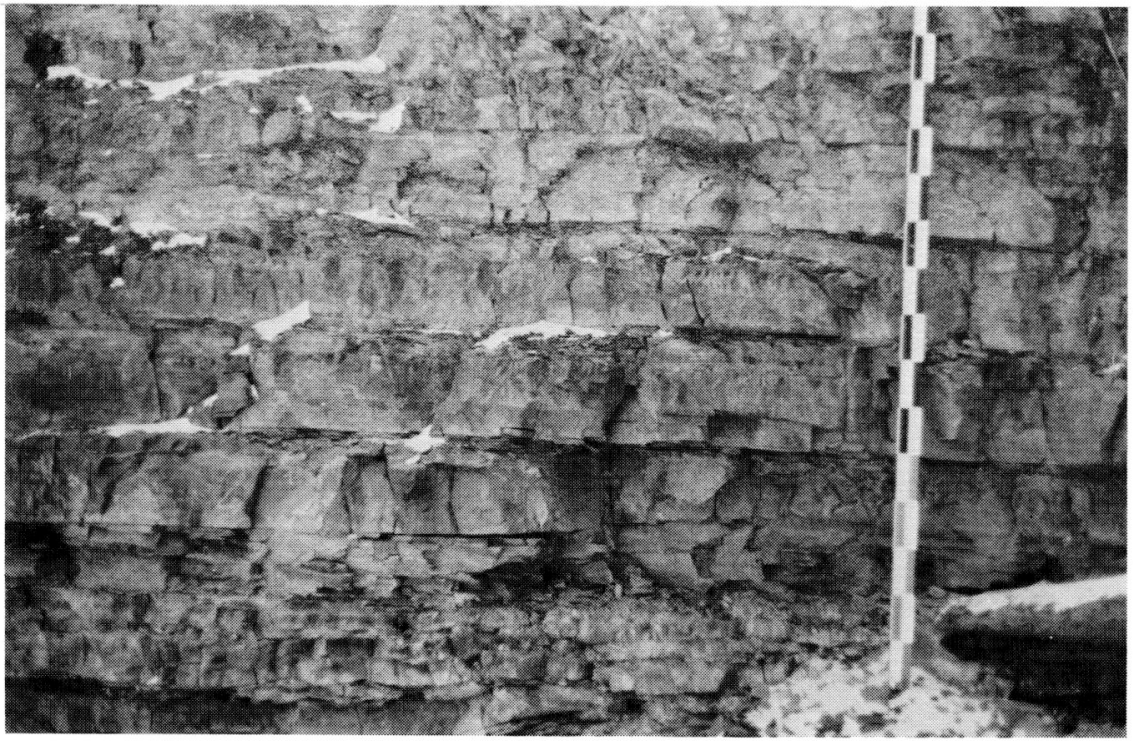




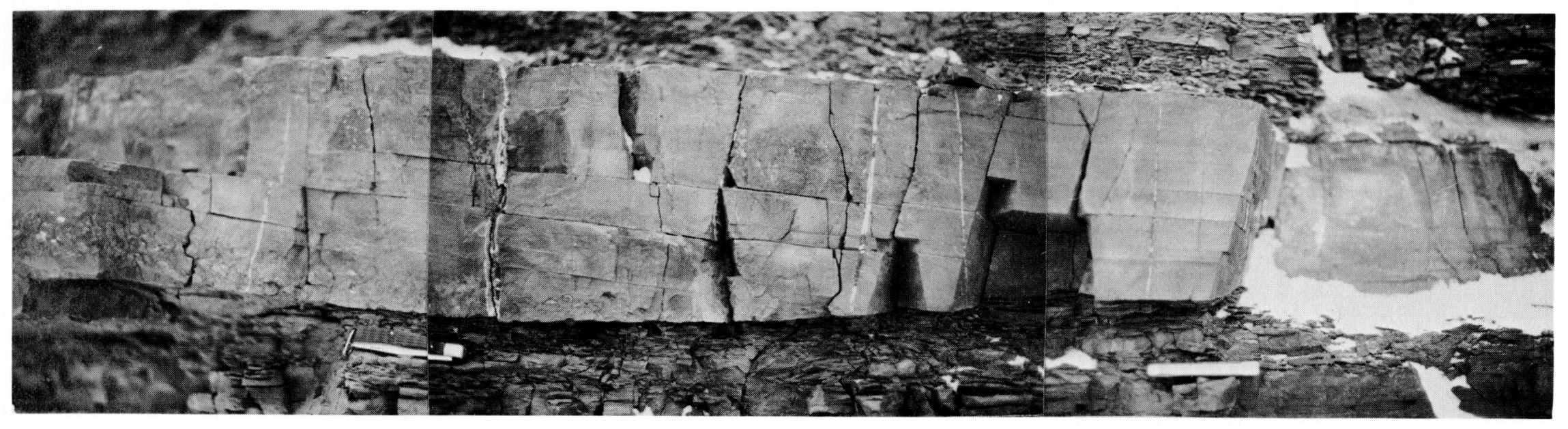

Fig. 22 Lenticular bed (megaripple) of very fine-grained sandstone with coquina lens in the basal portion of the bed (left half of photo), upper member, Ross Brook Formation (Stop 13). Note low-angle cross-lamination and sharp lower and upper contacts with finer-grained sediments.

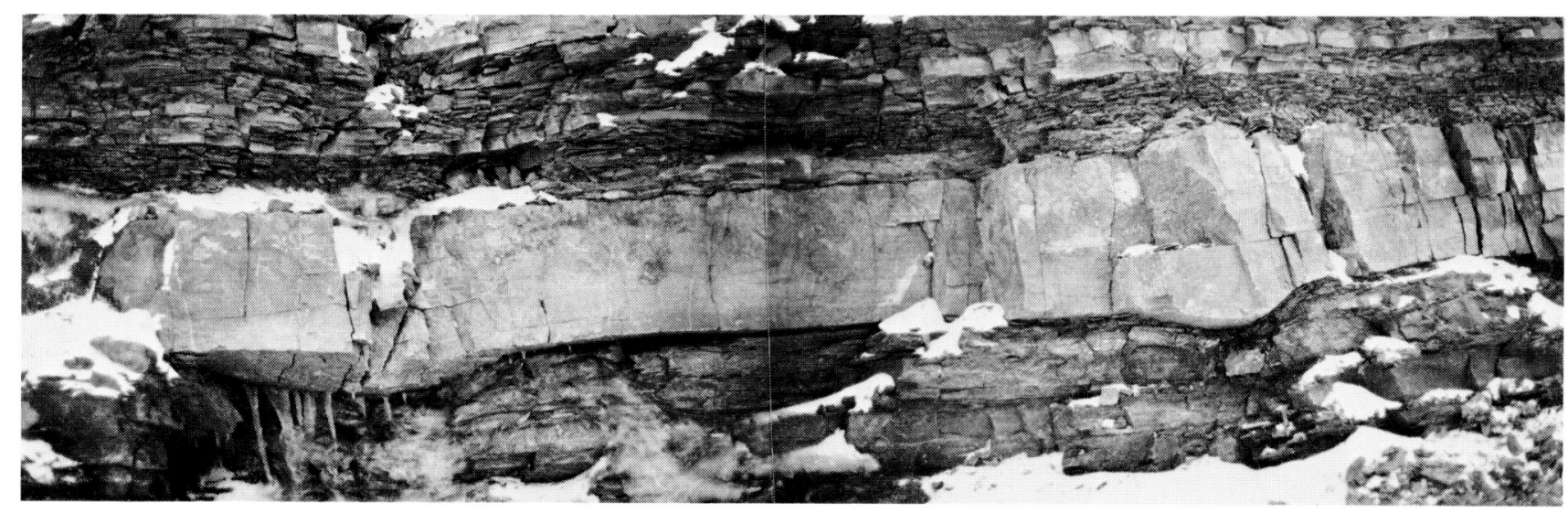

Fig. 23 Sandstone bed (the same as that shown in Fig. 22, but several metres to the right) with thinly interbedded siltstone and mudstone above and below, upper member, Ross Brook Formation (Stop 13). Note scour-and-fill structures at the base of the sandstone bed. 


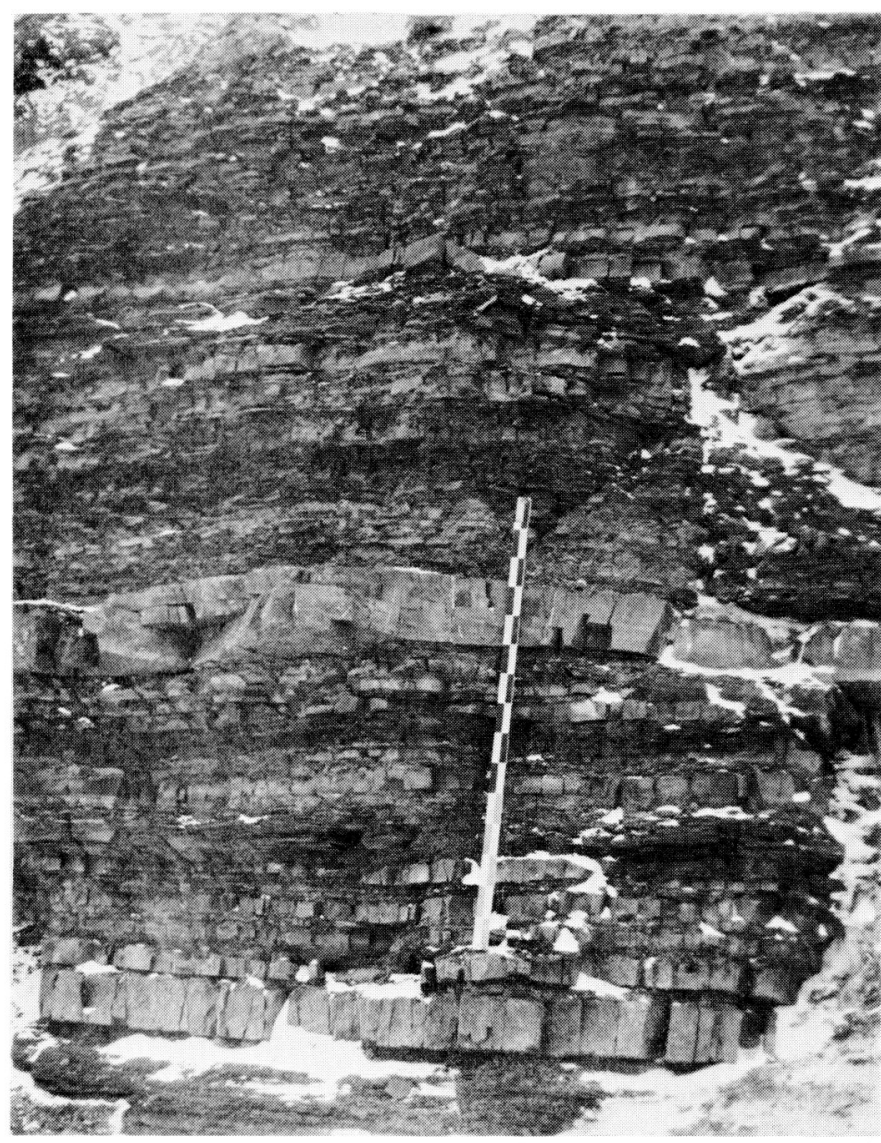

Fig. 24 Interbedded sand. stone, siltstone and mud. stone, upper member, Ross Brook Formation (Stop 13). Two relatively thick sando stone beds, one immediato ely below and the other towards top of the measuring stick are the same as those shown respectively in $\mathbf{F i g}$. 16 and Figs. 22 and 23 . Divisions on measuring stick are each $10 \mathrm{~cm}$.

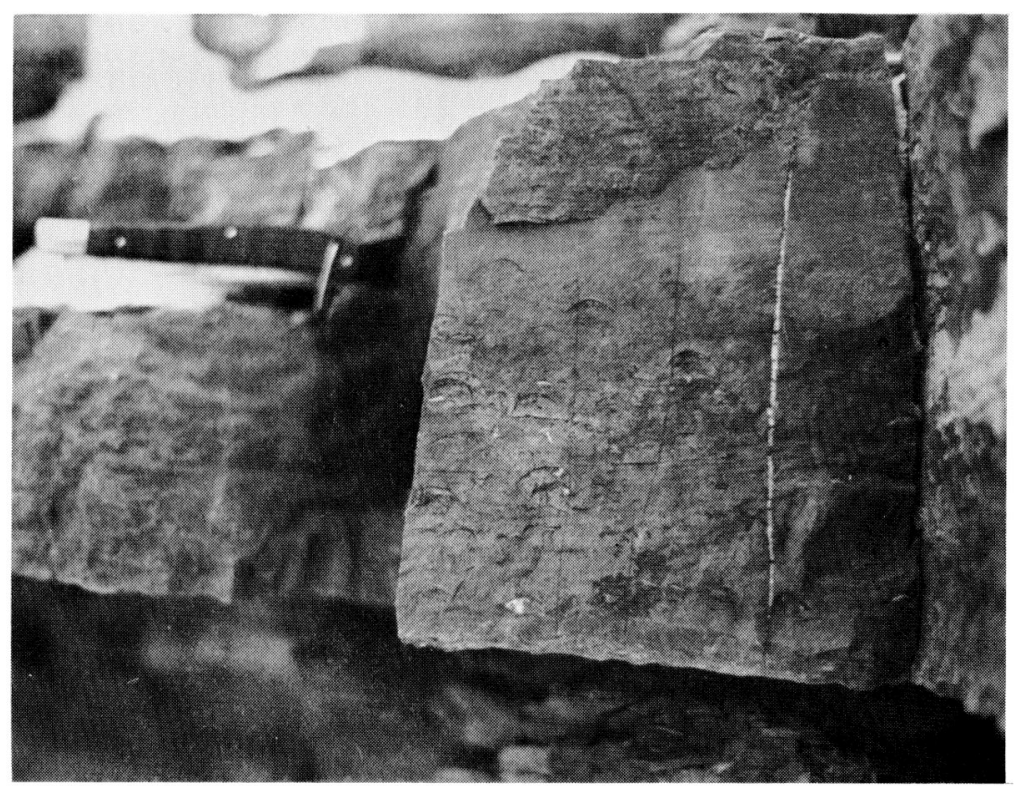

Fig. 25 Close-up view of sandstone bed shown in Figs, 22, 23 and 24. Note position of brachiopod shells, most of which are convex-up.

Fig. 26 Interbedded siltstone and mudstone, upper member, Ross Brook Formation (Stop 13). Note lateral continuity of siltstone beds and the undulatory (erosional) lower cono tacts of siltstone beds in the centre of the photograph. Each division of measuring stick is $10 \mathrm{~cm}$ long.

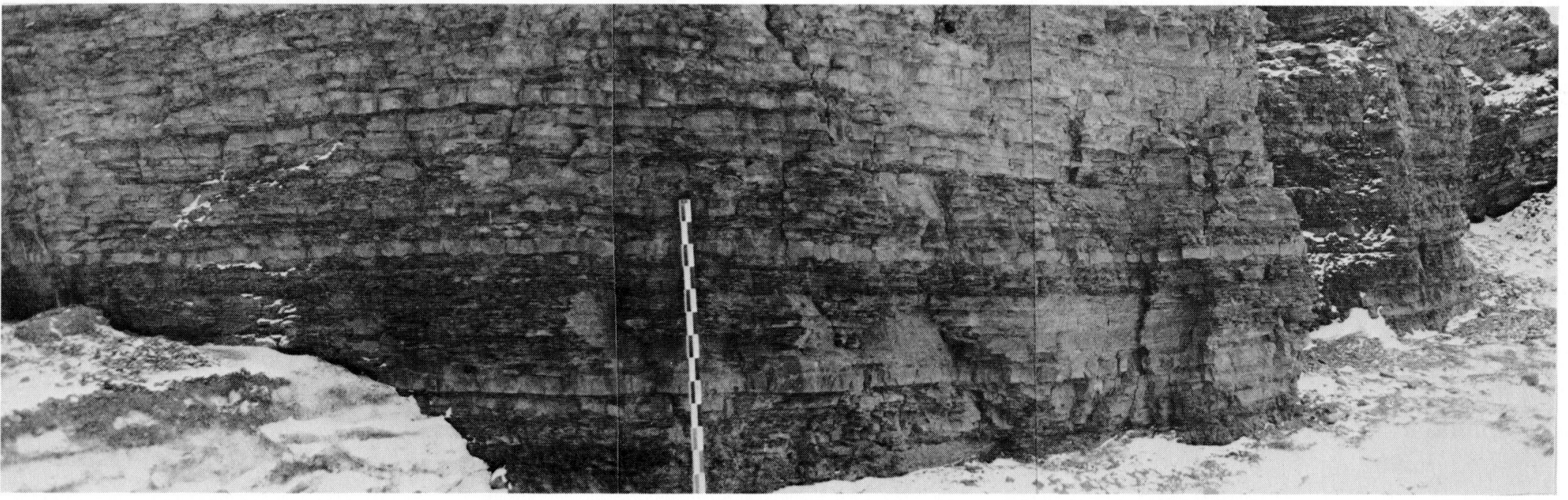


Moydart and Stonehouse Formations (Stop 14)

The Moydart and overlying stonehouse Formations (Fig. 37) are approximately $530 \mathrm{~m}$ thick. They are composed primarily of interbedded siltstone and mudstone, with subsidiary coquinite and fine-grained sandstone. These strata are comparable in many respects to the rocks of the upper member of the Ross Brook Formation. Yowever, the Moydart and Stonehouse strata are more calcareous, contain more coquinite lenses and are more highly fossiliferous.

The siltstone beds of the Moydart and Stonehouse Formations typically have both parallel- and crosslamination and sharp, often erosional bases. Scourdepressions filled with coquinas are common. The sedimentary structures (coquina-filled scourdepressions, interference ripples, etc.) indicate a dominantly shallow, wave-agitated seafloor. Parts of the section consist predominantly of mudstone, which tends to be massive and extensively bioturbated. Both the Moydart and stonehouse Formations grade upward into terrestrial deposits. The upper $10 \mathrm{~m}$ of the Moydart Formation consists of massive red siltstone and mudstone with pedogenic carbonate horizons. The stonehouse Formation is conformably overlain by the Knoydart Formation, which consists of alternating alluvial red sandstone to mudstone sequences. The upper beds of the stonehouse Formation have a distinctive green colour, which possibly is due to marine reduction of iron-rich muds derived from a nearby land source.

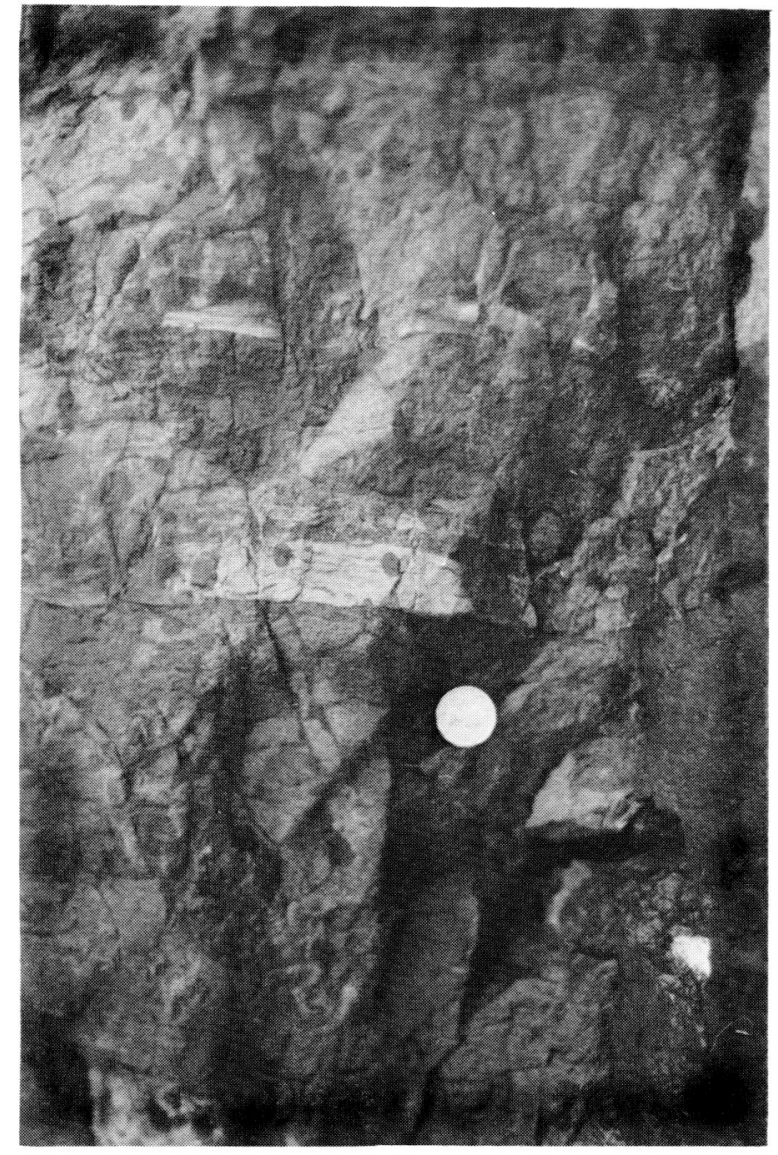

Fig. 28 Interbedded siltstone and mudstone, Green Member, Moydart Formation. Burrows are visible as dark patches in light coloured siltstone (Stop 14). Coin is a Canadian 5-cent piece.

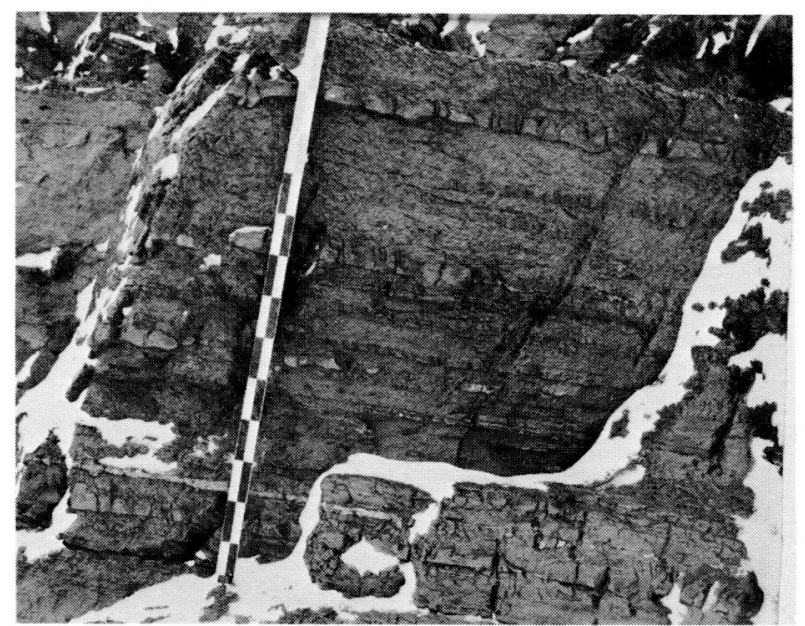

Fig. 27 Bioturbated mudstone, with interbeds of siltstone and scattered coquina lenses, middle part of Green Member, Moydart Formation (Stop 14). Load-deformed scour-depressions are common on undersurfaces of the siltstone beds. Each division of measuring stick is $10 \mathrm{~cm}$ long. 
Fig. 29 Interbedded mudstone, siltstone and coquinite, middle part of Green Member, Moydart Formato ion (Stop 14). In centre of photo coquinite lens is succeeded upward by siltstone with lowo angle crossolamination, which in turn is suco ceeded by muddy siltstone and mudstone. Coin is a Canadian 5-cent piece.
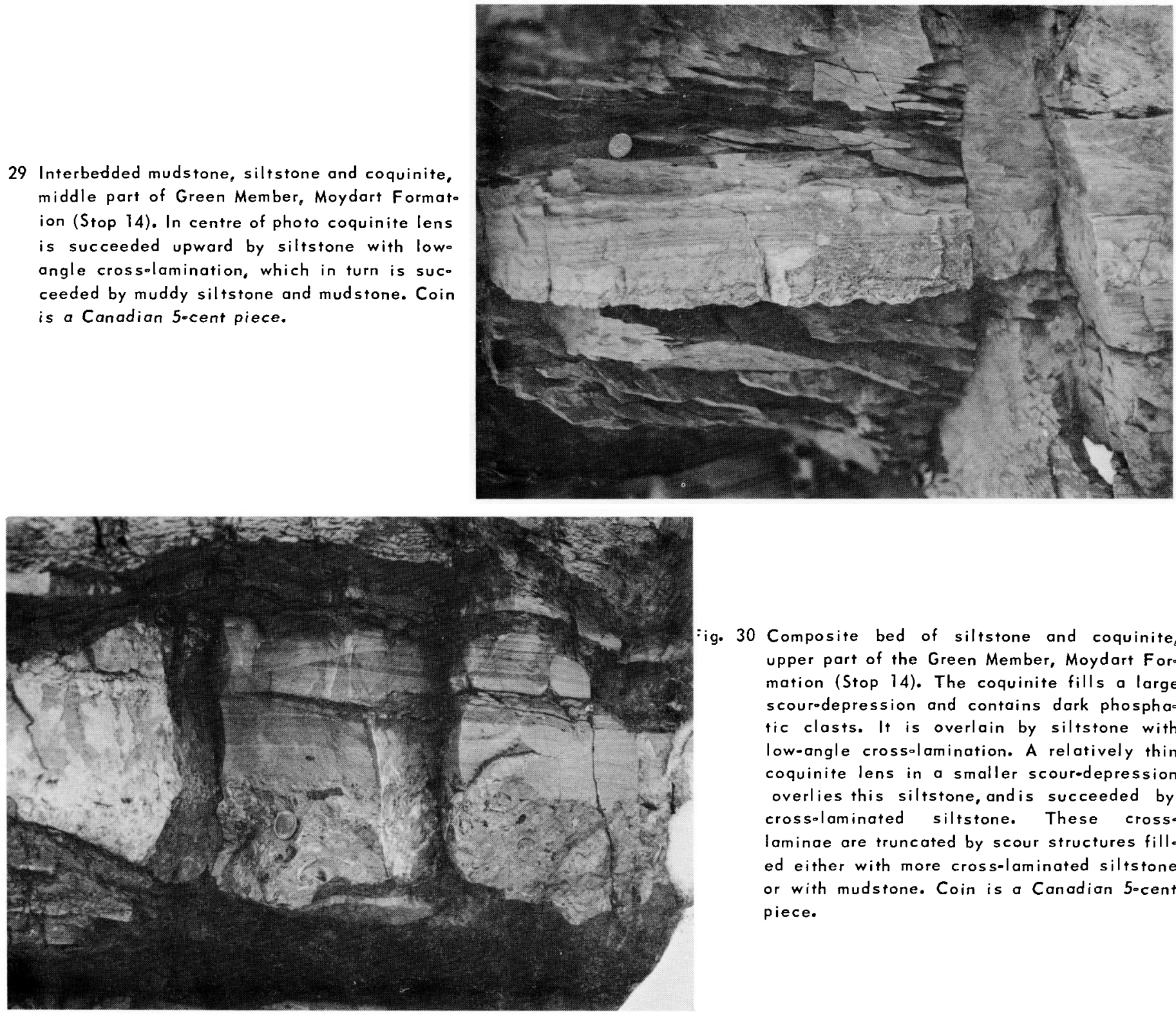

ig. 30 Composite bed of siltstone and coquinite, upper part of the Green Member, Moydart For mation (Stop 14). The coquinite fills a large scourodepression and contains dark phosphatic clasts. It is overlain by siltstone with low-angle crossolamination. A relatively thin coquinite lens in a smaller scour-depression overlies this siltstone, andis succeeded by crossilaminated silistone. These cross. laminae are truncated by scour structures fill. ed either with more cross-laminated siltstone or with mudstone. Coin is a Canadian 5ecent piece.

Fig. 31 Bed of laminated siltstone with coquinite at base and grading into silty mudstone at top. upper part of Green Member, Moydart Formation (same bed as that illustrated in Fig. 30 . viewed from a different angle. Note irregular, erosional base and ripple crossolamination near top of bed. Coin is a Canadian 5-cent piece.

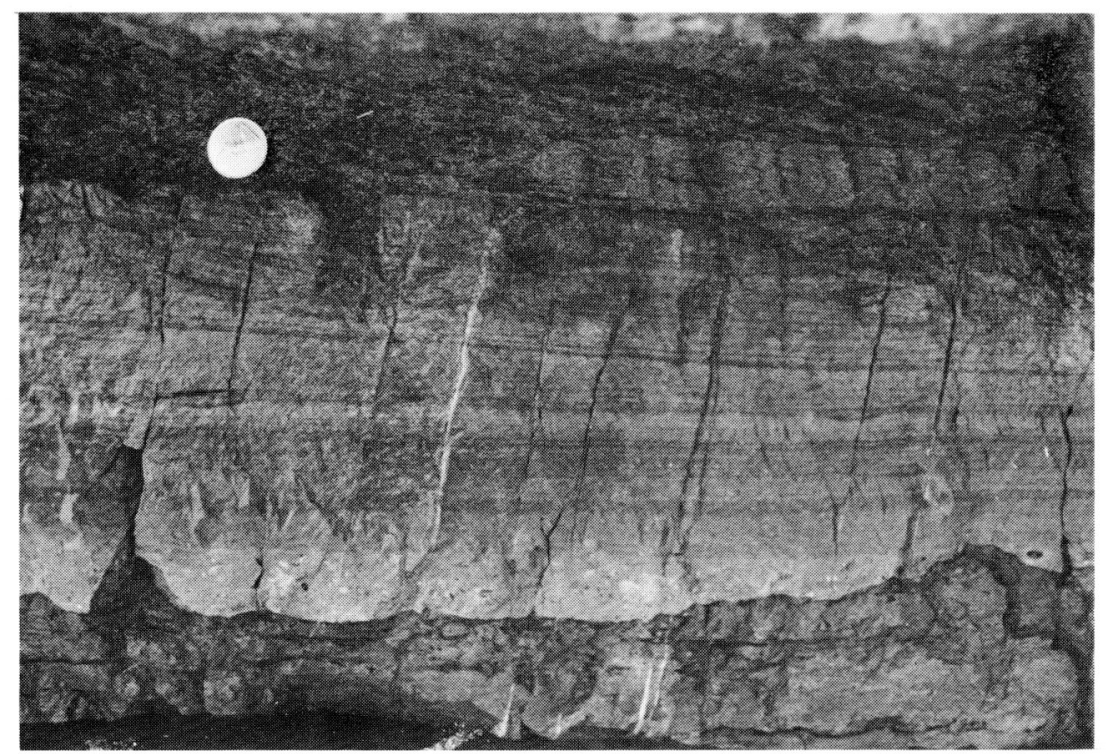



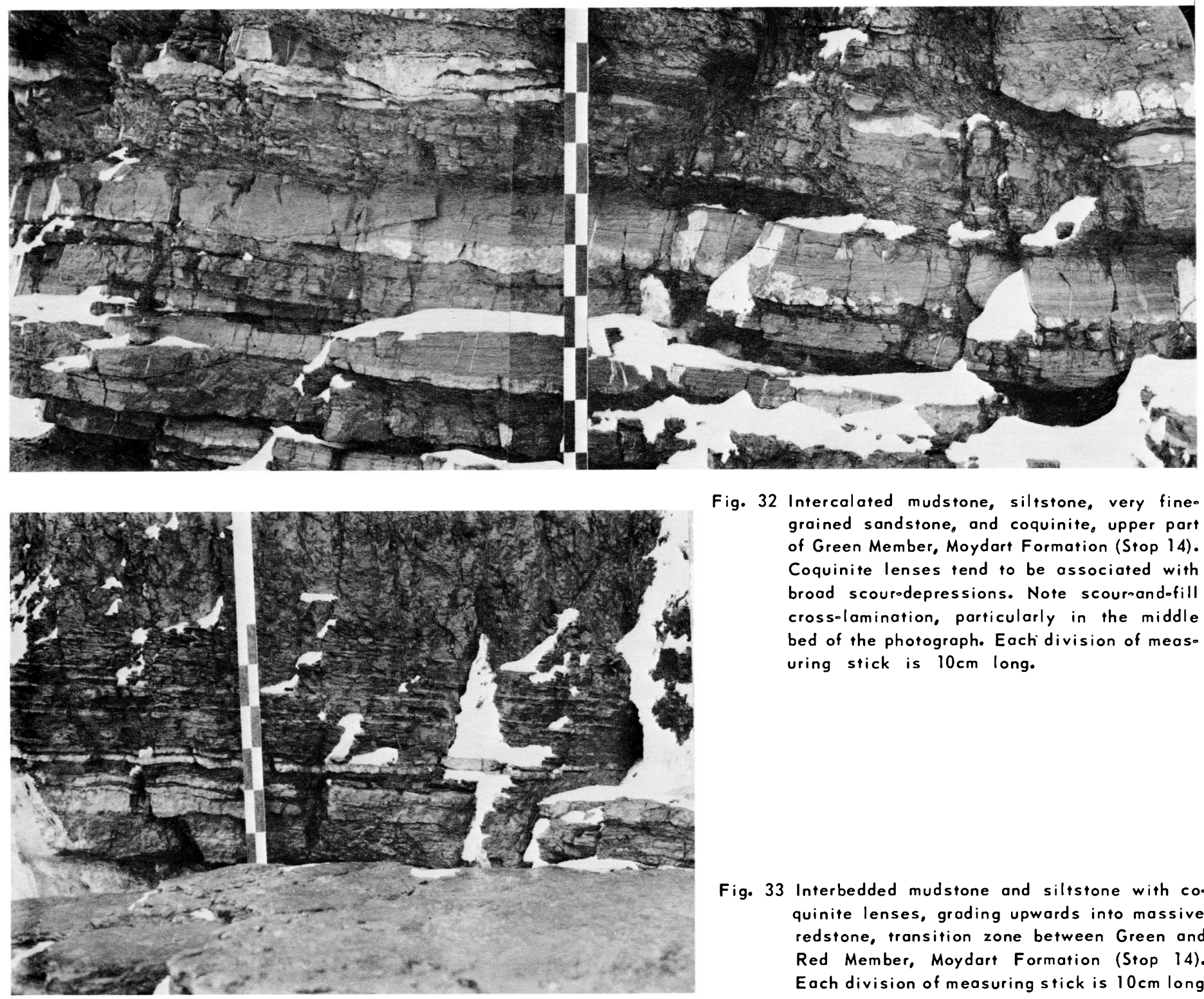

Fig. 32 Intercalated mudstone, siltstone, very fine. grained sandstone, and coquinite, upper part of Green Member, Moydart Formation (Stop 14). Coquinite lenses tend to be associated with broad scourodepressions. Note scournandefill cross-lamination, particularly in the middle bed of the photograph. Each division of meas. uring stick is $10 \mathrm{~cm}$ long.

Fig. 33 Interbedded mudstone and siltstone with coo quinite lenses, grading upwards into massive redstone, transition zone between Green and Red Member, Moydart Formation (Stop 14). Each division of measuring stick is $10 \mathrm{~cm}$ long.

Fig. 34 Red mudstone with lightocoloured carbonate

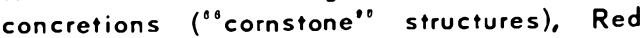
Member, Moydart Formation (Stop 14).

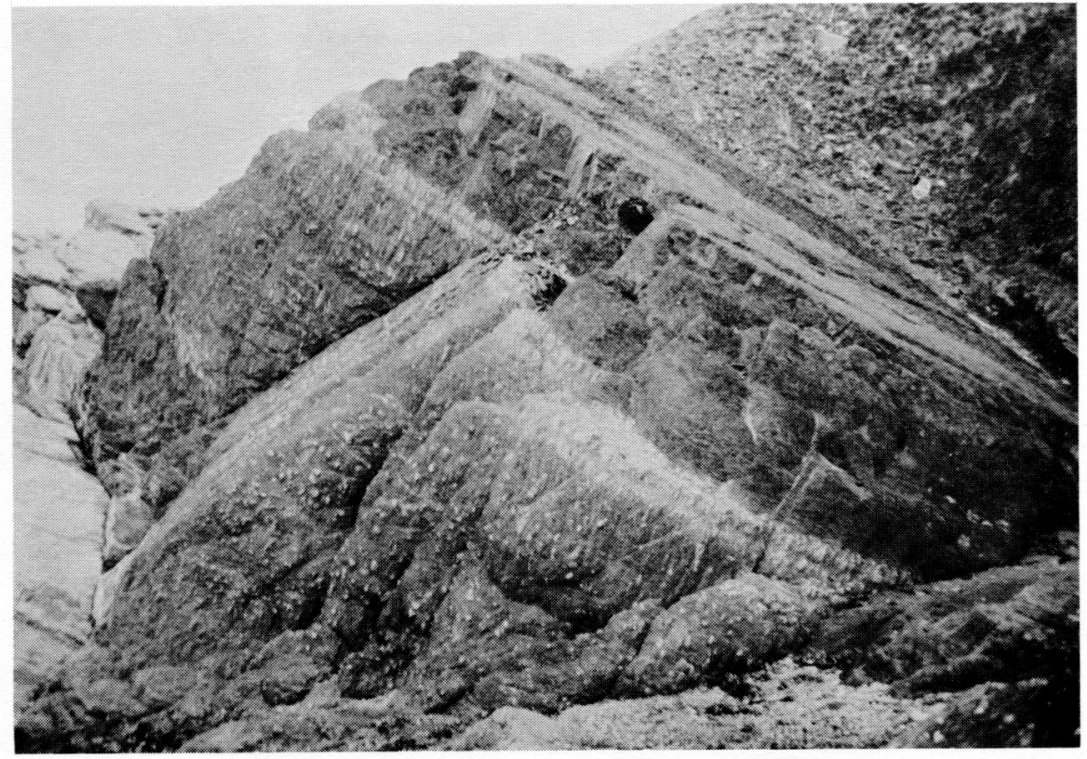




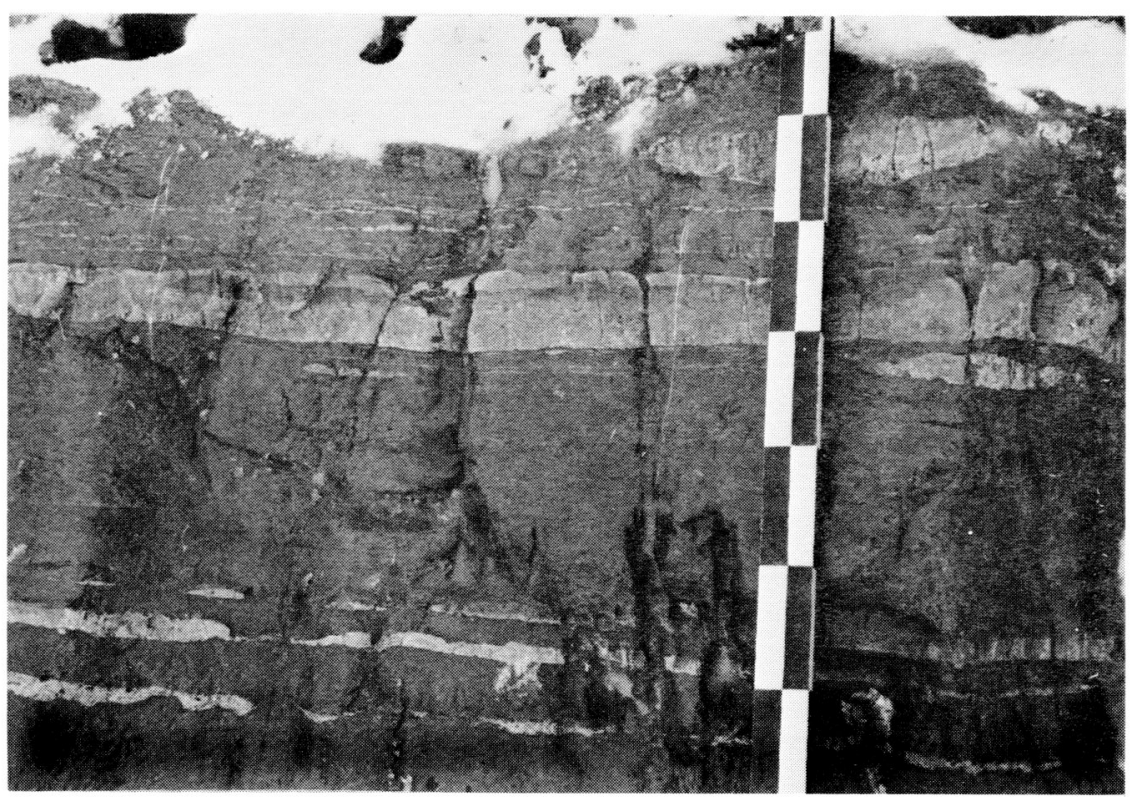

Fig. 35 Highly bioturbated mudstone and lenticular interbeds of siltstone and coquinite (with dark phosphatic clasts), lower member, Stonehouse Formation (Stop 14). Each division of measuring stick is $10 \mathrm{~cm}$ long.

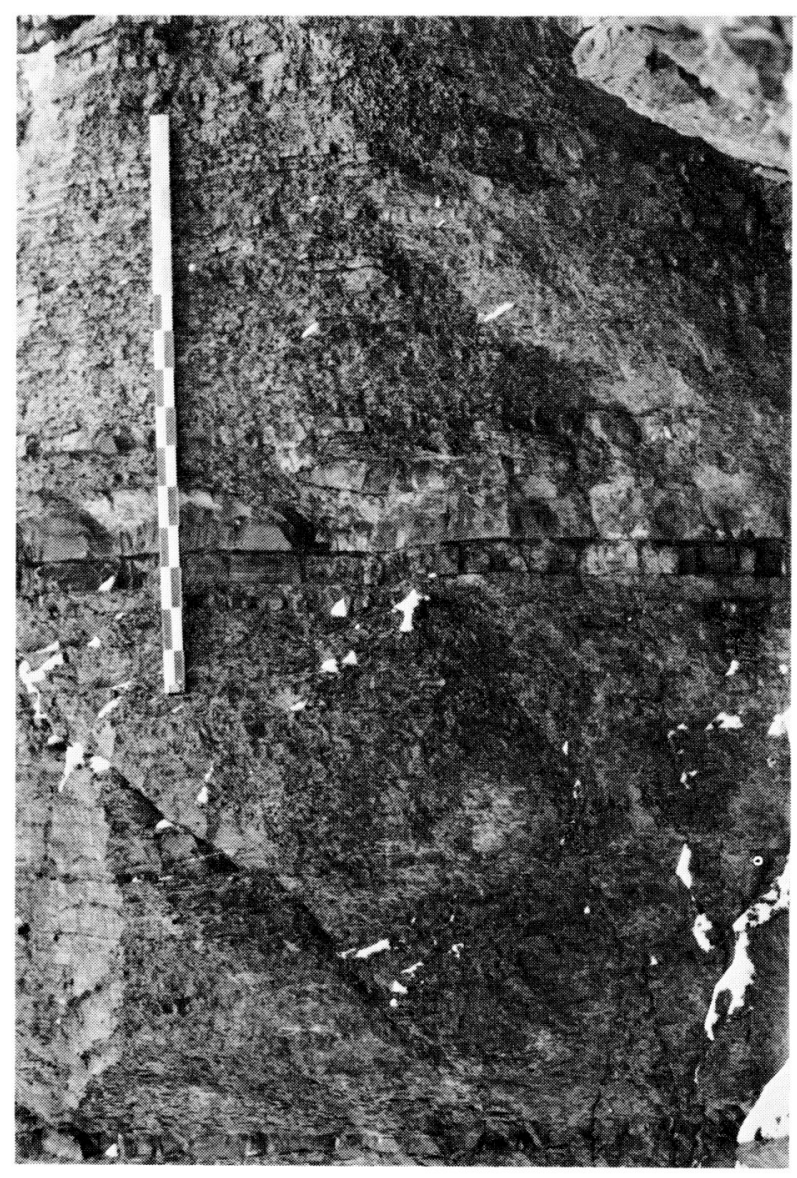

Fig. 36 Mudstone with subsidiary interbeds of silto stone, basal part of lower member, Stonehouse Formation (Stop 14). Each division of measure ing stick is $10 \mathrm{~cm}$ long.

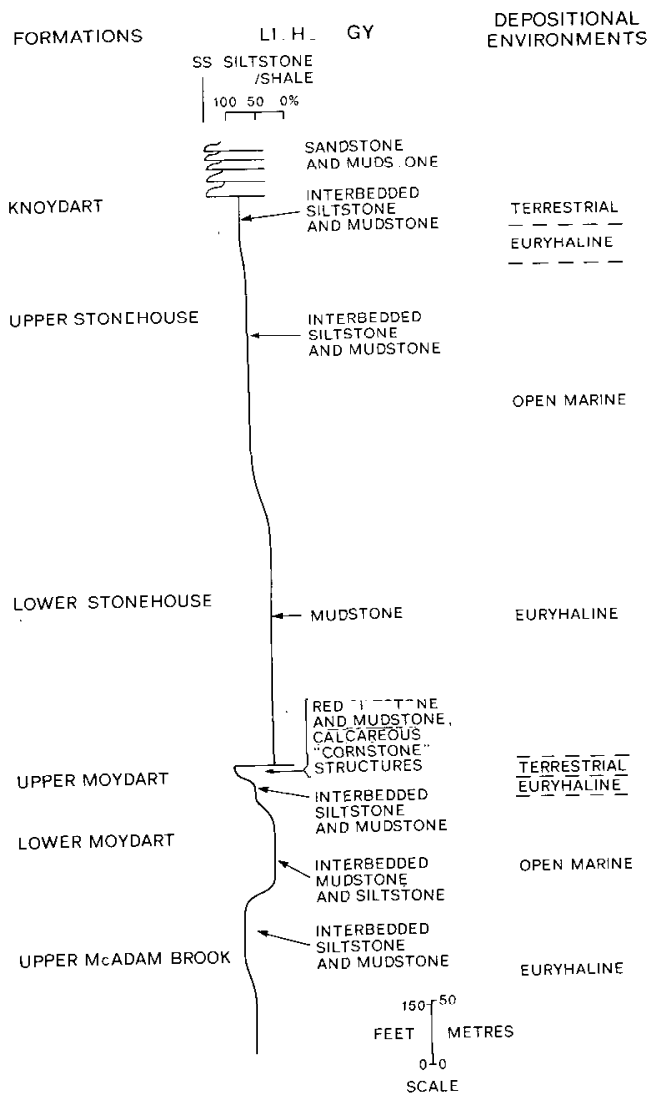

Fig. 37 Stratigraphy of the upper part of the Arisaig. Group (Moydart Point to McAras Brook). 


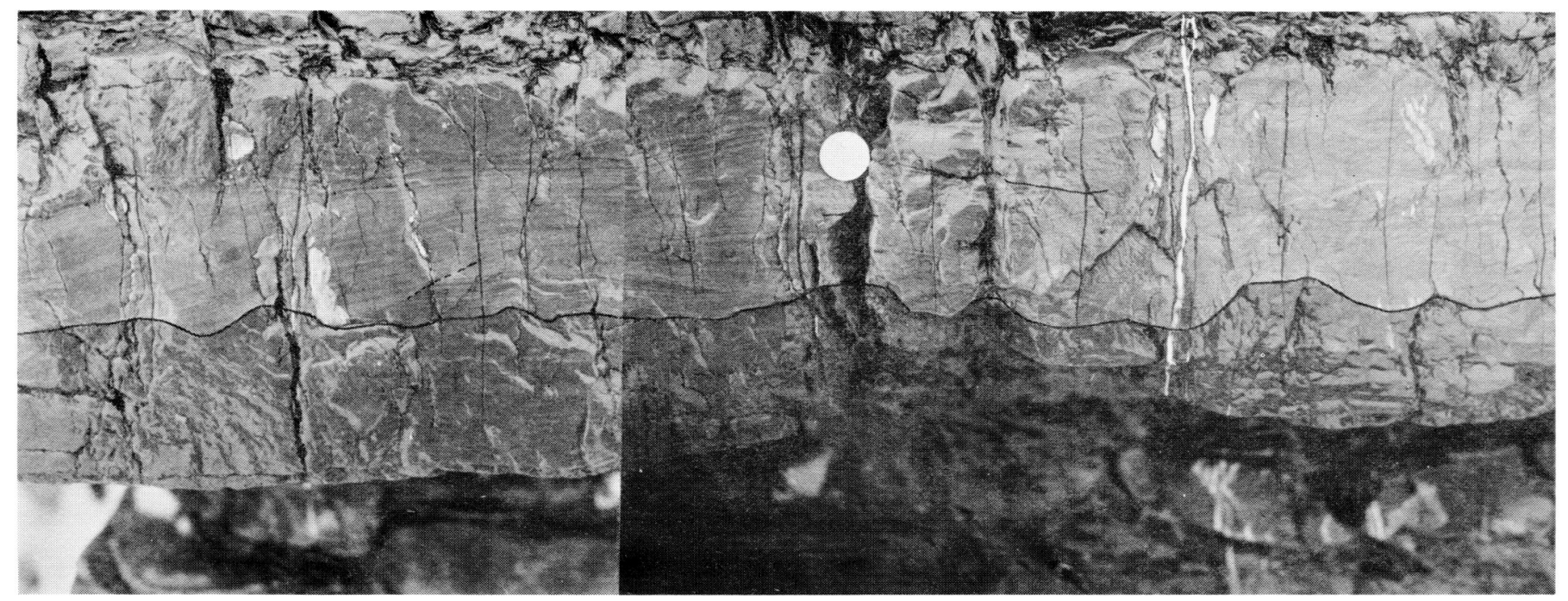

Fig. 38 Siltstone with highly developed scour-and-fill cross-lamination, in sharp erosional contact with silty mudstone below and in gradational contact with mudstone above, middle part of Stonehouse Formation (Stop 14). Coin is a Cane adian 25 -cent piece.
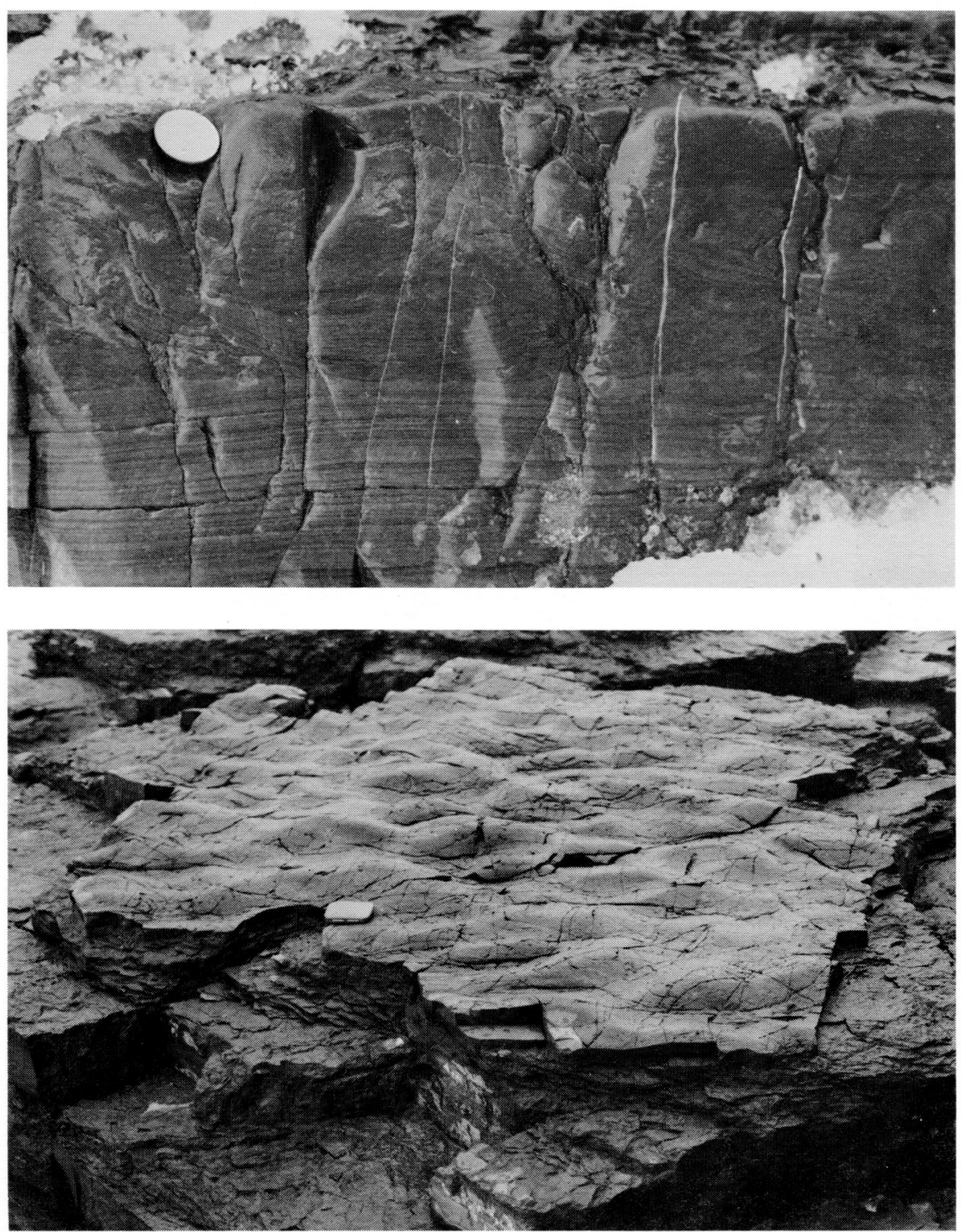

Fig. 39 Siltstone bed with parallele and convolute-lamination, grading upward into structureless mudstone, middle part of Stonehouse Formation (Stop 14). Coin is a Canadion 25. cent piece.

Fig. 40 Interference ripple marks at upper surface of a siltstone bed, middle part of Stonehouse Formation (Stop 14). Scale indicated by $8 . \mathrm{cm}$ long keycase. 
Fig. 41 Relatively thick siltstone beds interlayed with mudstone, middle part of Stonehouse Formation (Stop 14). Measuring stick is $1.5 \mathrm{~m}$ long.

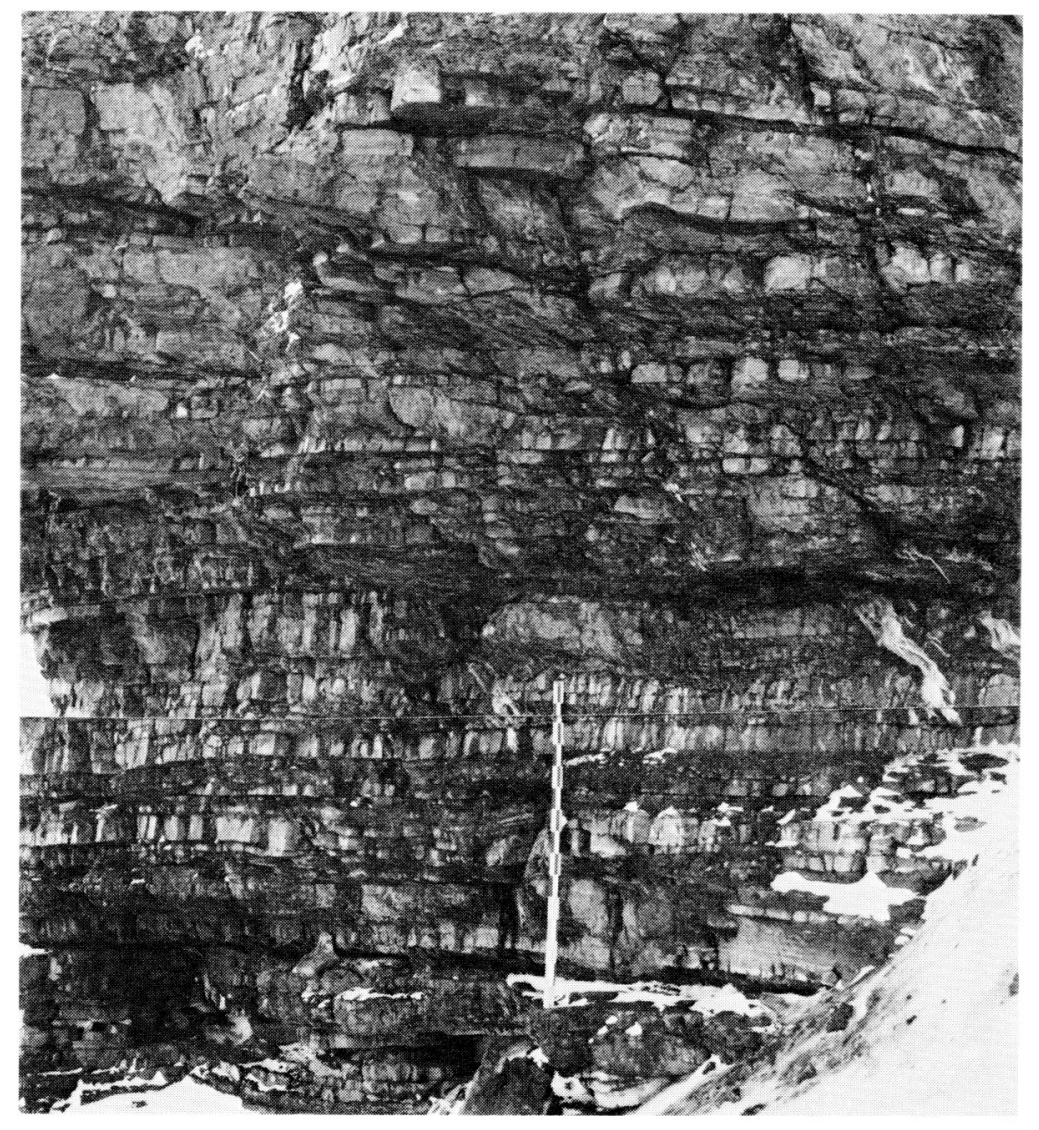

Fig. 42 Intercalated siltstone and mudstone, middle part of the Stone. house formation (Stop 14). The silistone beds have parallel-and low-angle cross-lamination, shal. low scour-depressions at their bose, sharp lower contacts, gradational upper contacts, and bioturbated tops. Bar at upper right represents approximately $2 \mathrm{~cm}$.

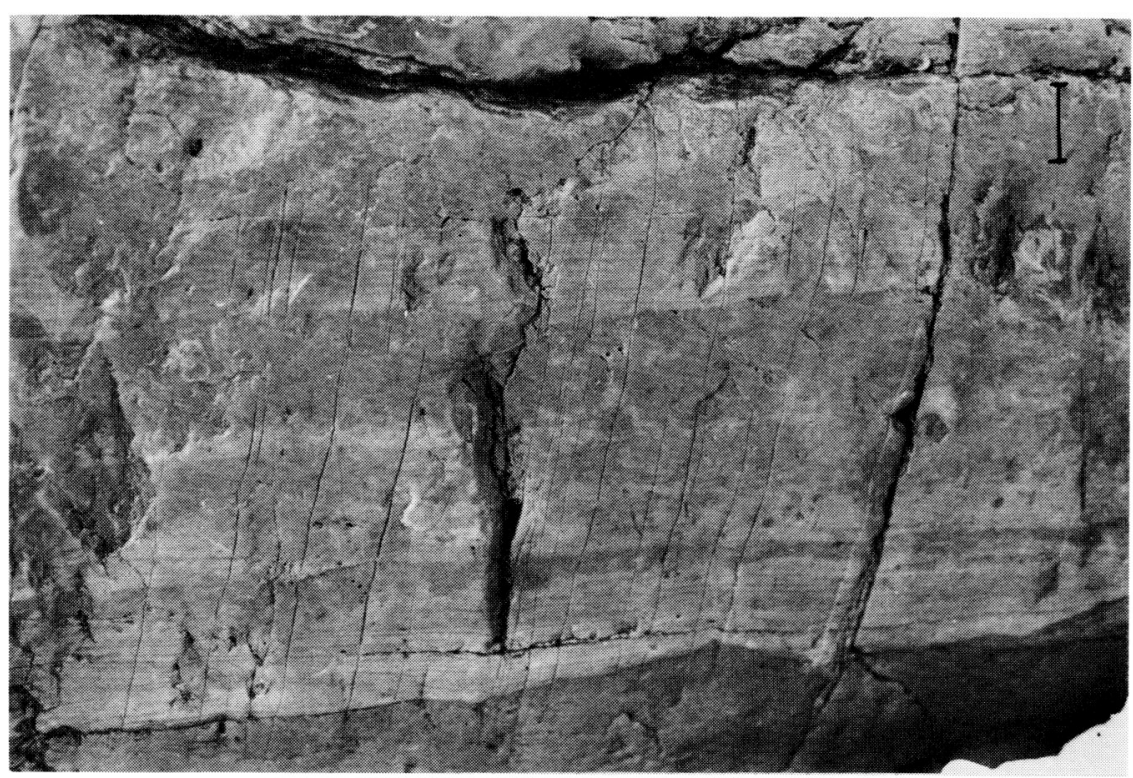



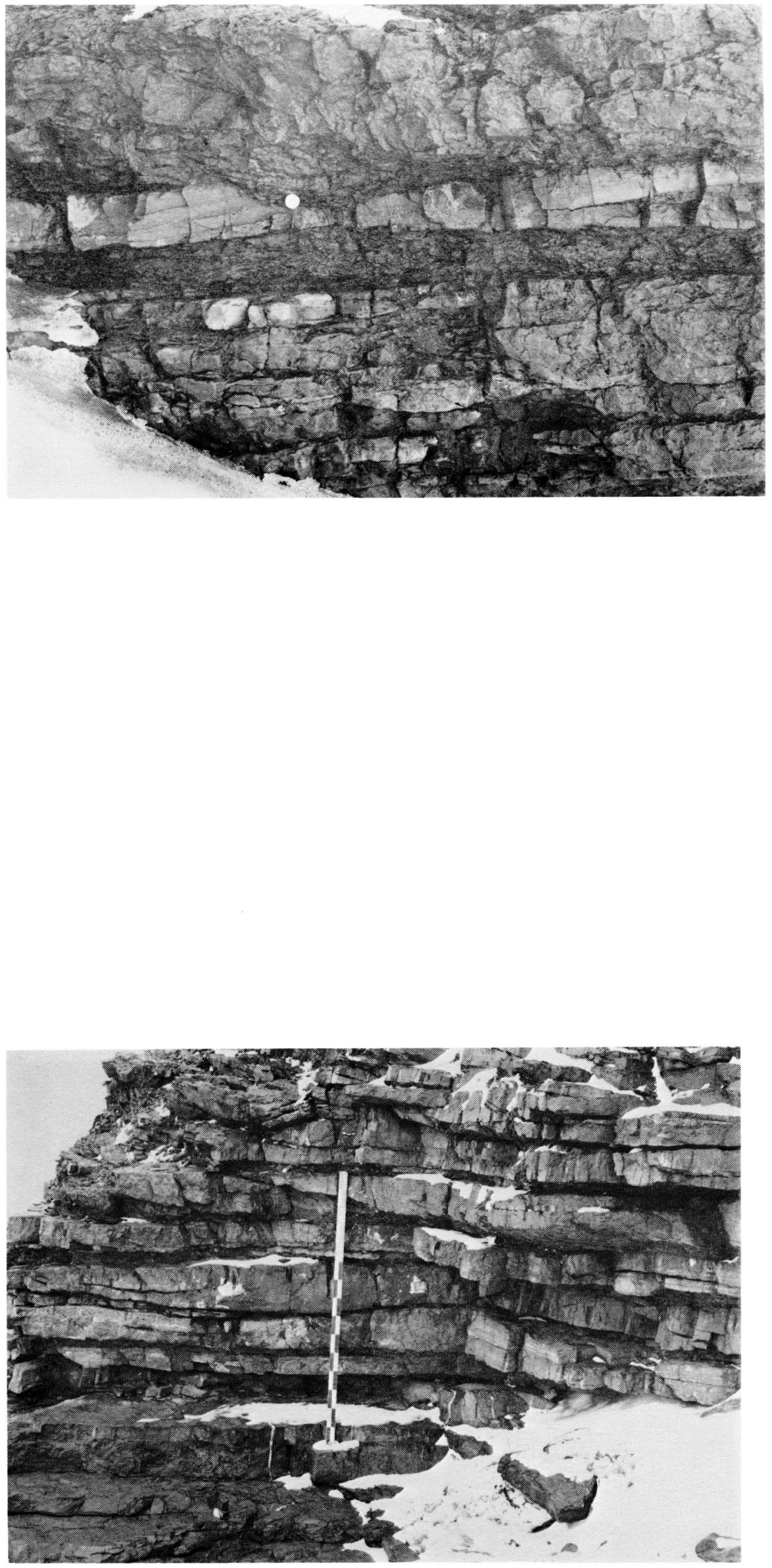

Fig. 43 Interbedded siltstone and mudo stone, with minor sandstone and coquinite, middle part of Stonehouse Formation (Stop 14). Note lenticular nature of silfstone beds and the scoure structure infilled with mud. stone above coin (Canadian 25-cent piece).
Fig. 44 Interbedded siltstone, mudstone, and coquinite, lower part of the upper member, Stonehouse Formation (Stop 14). Note un. dulatory upper bedding sur= faces and very lensey nature of the siltstone beds. Length of measuring stick is $1.5 \mathrm{~m}$. 


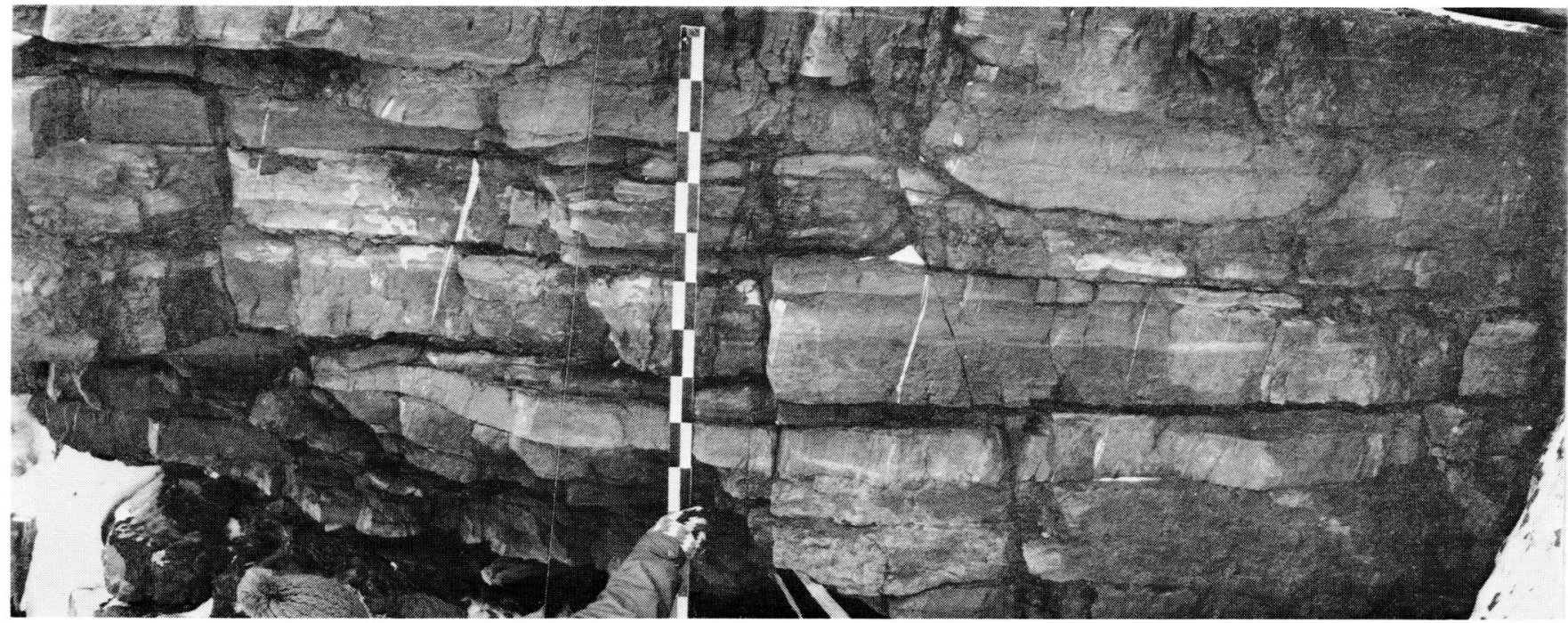

Fig. 45 Lenticular, highly laminated siltstone, thin interbeds of mudstone, and minor coquinite, lower part of the upper member, Stonehouse Formation (Stop 14). Each division of measuring stick is $10 \mathrm{~cm}$ long.

Fig. 46 Interbedded siltstone and mudstone, subsidiary lens. es of coquinite, and minor very-fine grained sand. stone, upper member, Stonehouse Formation (Stop 14). Scale indicated by hammer at base of thickest siltstone bed.

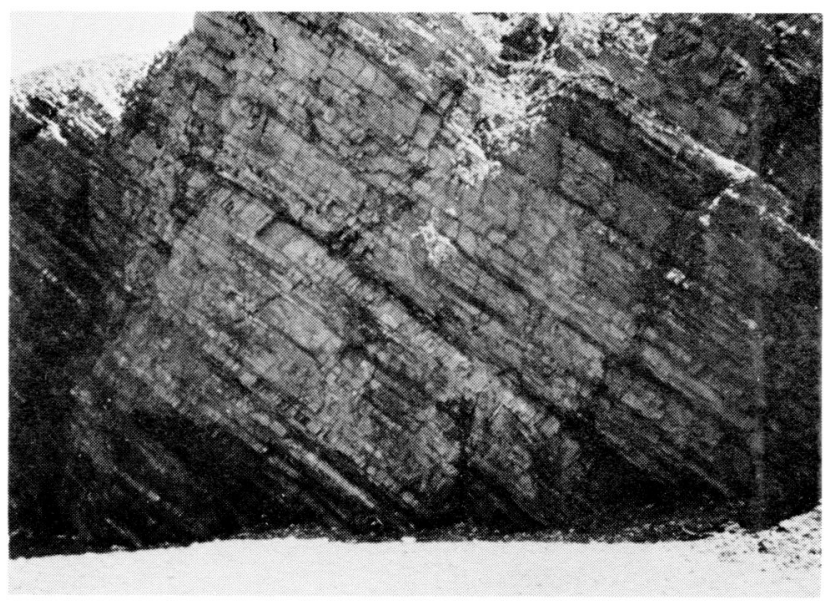

Green Member of the Moydart Formation. The Moydart Formation is divided into a lower "Green Member" and an upper "Red Member". The Green Member is composed of massive siltstone, silty shale, massive calcareous siltstone and thin layers and lenses of shelly limestone (coquinite). This member can be subdivided into three parts: The basal $9 \mathrm{~m}$ has 60-80z siltstone. The siltstone beds commonly have parallel- and cross-lamination, basal coquinas and interference ripple marks. The mudstone beds contain crinoid stems in their growth positions, suggesting preservation by rapid burial but relatively mild current activity. Other organic remains include in situ bryozoans and possibly algae.

The middle part of the Green Member consists primarily of massive-appearing, highly bioturbated mudstone. A few thin beds of laminated siltstone ( $5 \mathrm{~cm}$ thick) are present as well. Burrows and trails of organisms commonly disrupt these siltstone beds (Figs. 27 and 28 ). Load casts occur on the under-surfaces of most of the siltstone beds (Fig. 27), presumably because the silt was deposited rapidly on a highly water-laden substrate of bioturbated mud.

In the upper part of this member, highly laminated siltstones (from 0.5 to $20 \mathrm{~cm}$ thick) are abundant. Coquinas, vertical burrows and interference ripple marks are prevalent. Each of a number of siltstone beds appear to be composed of a series of megaripples(?) with low-angle crosslamination. Several of these beds are illustrated in Figure 32. Note the coquina lenses at the base of these beds, beneath the foreset-lamination of the megaripples. The sedimentary structures of this part of the Moydart Formation pepresent a general increase in current-energy and an associated increase in sediment influx, such that biogenic reworking was reduced and, as a consequence, irimary structures are relatively well-preserved. These sedimentary characteristics probably developed in response to shoaling, preceding the overlap of the red strata discussed below.

Red Member of the Moydart Formation. The Red Member consists of massive red mudstones, with 
gradationally interbedded green siltstones in the lower part. Concentrations of calcareous "cornstone" structures denote layers of pedogenic carbonate (Fig. 34). These bodies are residuals of a former subaerial weathering zone. The marine siltstones that occur near the base of the unit are highly laminated. These silty strata grade upward into massive red mudstones (Fig. 33). Linguloid brachiopods and fresh-water fish spines denote lowsalinity conditions.

The Stonehouse Formation is composed of mudstone, calcareous siltstone and shelly limestone (coquinite), generally similar to the strata of the Moydart Formation. The stonehouse is divided into a lower, muddy member and an upper member consisting of alternating siltstone and shale beds. The lower member consists of mudstone $(70 \%$ by volume), with relatively thin siltstone beds (30\% by volume). Some of the siltstone beds are lenticular, presumably as a result of low influxes of silt that produced only starved ripples (Fig. 35). Interference ripples and coquinites are abundant. Benthonic fossils are sparse, suggesting a lowsalinity, nearshore regime.

The upper member consists of siltstone and mudstone beds that range in thickness from 5 to $30 \mathrm{~cm}$. The siltstonesoccur both as laterally continuous and uniformly thick beds and as lenticular beds that laterally pinch out over distances of less than several metres (Fig. 44). Some beds have graded divisions up to $20 \mathrm{~cm}$ in thickness. The mudstone beds tend to be completely reworked by infauna, but only the upper part of the siltstone beds show the effects of extensive burrowing (Fig. 42). A diverse, normal-marine, shelly fauna is represented, especially in the coquinite lenses. The generally disarticulated shells accumulated as lag deposits typically in closely-spaced scour-depressions (Figs. 43 and 44). Conditions of high-energy erosion and deposition above wave-base are indicated by the combination of sedimentary structures that characterize these beds, including scour-structures (Figs. 38, 43 , 44 and 45), megaripples (Fig. 53), convolute lamination (Fig. 39), and interference ripple marks (Fig. 40).

The strata of both the Stonehouse Formation and the lower Moydart Formation accumulated in a very shallow-water environment adjacent to an arid terrestrial plain (recorded by the occurrence of terrestrial deposits in the upper Moydart Formation and in the Knoydart Formation). The shallow bottom was within the photic zone, enabling algal(?) colonies and plant-grazing gastropods to flourish. Sea-bottom conditions varied from the slow accumulation of bioturbated muds to wave-agitated periods during which the substrate was strewn with transported shells and winnowed silts. At such times, the currents were sufficiently strong to scour the sea-bottom. Interference- and wave-ripple marks were formed by less vigorous wave action. The abundant shelly fauna suggest that the seas were warm and conditions were favourable for growth. Species were restricted primarily by fresh-vater dilution as shown by the fossil assemblages of the Green Member of the Moydart Formation and of the lowermost and uppermost strata of the stonehouse Formation. These brackish-water conditions resulted from proximity to land and estuary outlets and possibly also from isolation of water masses behind seaward shoals.
References

BAMBACH, R.K., 1969, Bivalvia of the Siluro-Devonian Arisaig Group, Nova Scotia; Unpubl. Ph.D. thesis, Yale University, New Haven, Conn. 376 p.

BERRY, W.B.N. and BOUCOT, A.J., 1970, Correlation of the North American Silurian rocks; Geol. Soc. Amer., Special Paper 102, $289 \mathrm{p}$.

BOUCOT, A.J., DEWEY, J.F., DINELEY, D.L., FYSON, W.K., HICKOX, C.F., MCKERROW, W.S , and ZIEGLER, A.M., 1974, Geology of the Arisaig area; Geol. Soc. Amer., Special Paper 139, 191 p.

GOLDRING, R., and BRIDGES, P., 1973, Sublittoral sheet sandstones; J. Sed. Pet., v. 43, p. 736-747.

HARPER, C.W., 1973, The Brachiopod fauna of the Arisaig Series (Silurian-Lower Devonian) of Nova Scotia; Geol. Surv. Can., Bull. 215, 163 p.

HAYES, M.O., 1967, Hurricanes as geological agents, South Texas Coast; Bull. Amer. Assoc. Petrol. Geol., v. 51, p. 937-942.

HOWARD, J.D., REINECK, H.E., 1972, Georgia coastal region, Sapelo Island, USA: Sedimentology and Biology IV - Physical and biogenic sedimentary structures of the nearshore shelf; Senckenbergiana Marit., v. 4, p. 81-123.

KULM, L.D., ROUSH, R.C., HARTLETT, J.C., NEUDECK, R.H., CHAMBERS, D.M., and RUNGE, E.J., 1975, Oregon continental shelf sedimentation: interrelationships of facies distribution and.sedimentary processes; J. Geol., v. 83, p. 145-175.

MAEHL, F.F., 1961, The older Paleozoic of Pictou County, Nova Scotia; Nova Scotia Dept. Mines, Mem. 4, $110 \mathrm{p}$.

MCKERROW, W.S. and ZIEGLER, A.M., 1971, The Lower Silurian paleogeography of New Brunswick and adjacent areas; J. Geol., v. 79, p. 635-646.

REINECK, H.E. and SINGH, I.F., 1972, Genesis of laminated sand and graded rhythmites in storm sand layers of shelf mud; Sedimentology, $v$. 18 , p. 123-128.

REINECK, H.E. and SINGH, I.B., 1973, Depositional sedimentary environments with reference to terrigenous clastics; Springer verlag, Berlin, $439 \mathrm{p}$.

SWIFT, D.J.P., KOFOED, J.W., SAULSBURY, F.B., and SEARS, P., 1972, Holocene evolution of the shelf surface, central and southern Atlantic shelf of North America, in Swift, D.J.P., Duane, D.B., Pikley, O.H. (Eds.), Shelf Sediment Transport: Process and Pattern; Dowden, Hutchinson and Ross Inc., Stroudsburg, Pa., 656 p.

WATKINS, R. and BOUCOT, A.J., 1975, Evolution of Silurian brachipod communities along the southeastern coast of Acadia; Geol. Soc. Pmer. Bull. v. 86, p. $243-354$.

EIEGLER, A.M., 1965, Silurian marine communities and their environmental significance; Nature, v. 207, p. $270-272$. 